\title{
Monodisperse and Polydisperse PEGylation of Peptides and Proteins: a Comparative Study
}

Jie Wang, ${ }^{\dagger}$ Tao Deng, ${ }^{\dagger}$ Yuntai Liu, ${ }^{\dagger}$ Kexin Chen, ${ }^{\dagger}$ Yongping Chen, ${ }^{\ddagger}$ Zhigang Yang, ${ }^{\dagger}$ and Zhong-Xing Jiang ${ }^{* \dagger}$

${ }^{\dagger}$ Hubei Province Engineering and Technology Research Center for Fluorinated Pharmaceuticals, School of Pharmaceutical Sciences, Wuhan University, Wuhan 430071, China.

the Affiliated Chaohu Hospital of Anhui Medical University, Department of Neurology, Chaohu 238000, China.

\section{Table of contents}

$\begin{array}{ll}\text { 1. General information } & \text { S2 }\end{array}$

2. Synthesis of M-PEG amino acid 5

3. Stability study of agents $\mathbf{1 - 4}$ in rat plasma S6

4. Biocompatibility assay of agents 1-4 S6

$\begin{array}{ll}5 . \text { Determination of } n \text {-octanol/water partition coefficients } & \text { S7 }\end{array}$

$\begin{array}{ll}\text { 6. Purity identification of proteins 15-18 } & \text { S7 }\end{array}$

7. PEGylated proteins structural analysis by Far-UV CD measurement S7

8. Hydrodynamic radius determination of proteins by dynamic light scattering $\quad$ S7

$\begin{array}{ll}\text { 9. Animal experiments } & \text { S8 }\end{array}$

10. Copies of ${ }^{1} \mathrm{H}$ NMR, ${ }^{13} \mathrm{C}$ NMR and MS spectra of compounds $\quad$ S9 


\section{General information}

Unless otherwise indicated, all reagents were obtained from commercial supplier and used without prior purification. DCM, DMF, MeOH and THF were dried and freshly distilled prior to use. Agents $\mathbf{3}$ and $\mathbf{4}$ were purchased from JenKem Technology (Beijing, China). DEAE Focurose 6FF column was purchased from Huiyan Bio (Wuhan, China). Flash chromatography was performed on silica gel (200-300 mesh) with $\mathrm{MeOH}$ and DCM as eluents. NMR spectra were recorded on a Bruker NMR spectrometer, operated at $400 \mathrm{MHz}$ for ${ }^{1} \mathrm{H}$ and $100 \mathrm{MHz}$ for ${ }^{13} \mathrm{C}$, using the solvent signal as the internal reference. Chemical shifts were expressed in ppm and coupling constants $(J)$ are in Hertz (Hz). The splitting patterns for ${ }^{1} \mathrm{H}$ NMR spectra are denoted as follows: s (singlet), $\mathrm{d}$ (doublet), dd (double doublet), t (triplet), q (quartet), and m (multiplet). ESI mass spectra were recorded on a Thermo Scientific Q Exactive Focus mass spectrometer. MALDI-TOF mass spectra were recorded on a Bruker Ultraflex III TOF/TOF spectrometer using the reflection mode for positive ions with $\alpha$ cyano-4-hydroxylcinnamic acid or sinapic acid as matrix. 


\section{Synthesis of M-PEG amino acid 5}

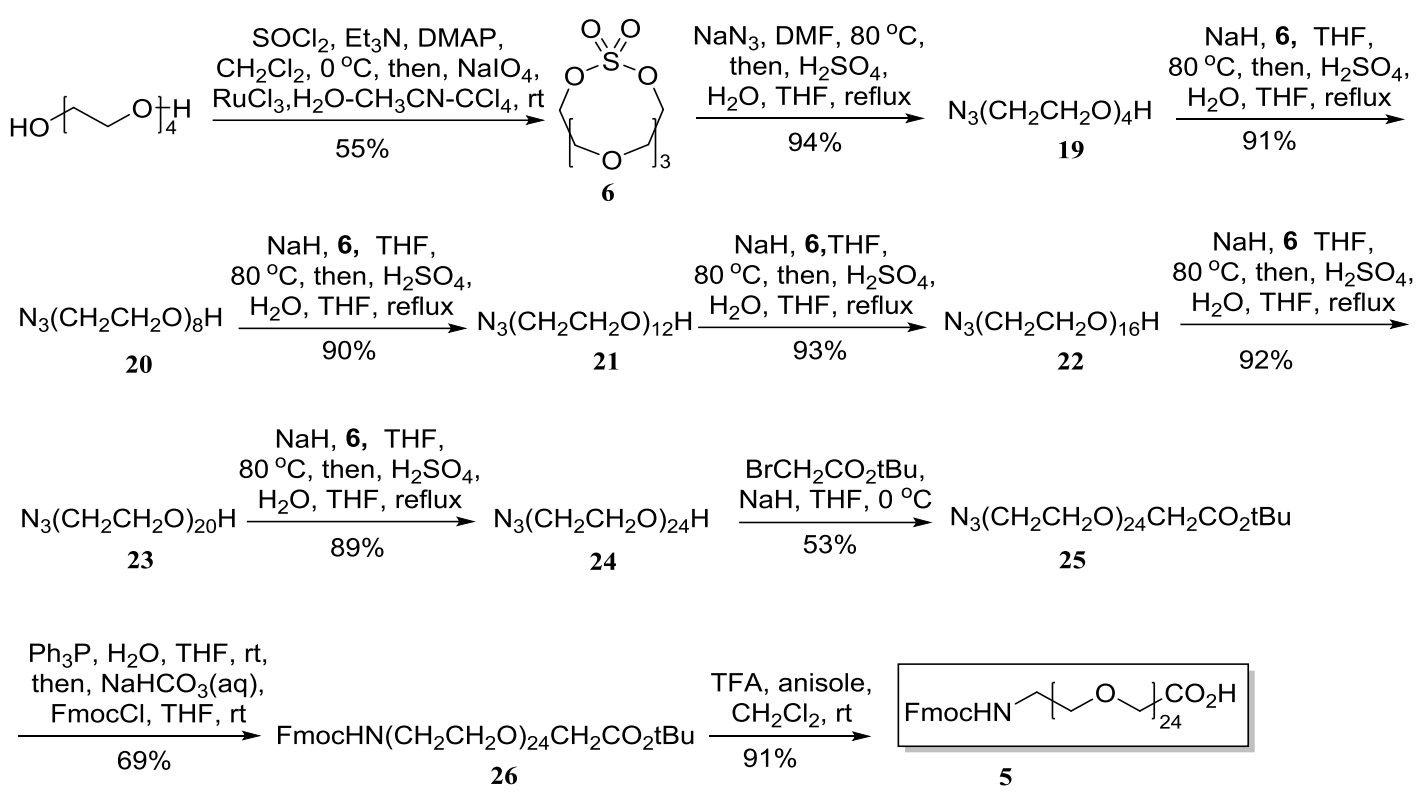

Scheme S1. Synthesis of M-PEG $\omega$-amino acid 5

Compound 6. Cyclic sulfate 6 was prepared with our previous method. ${ }^{[1]}{ }^{1} \mathrm{H}$ NMR $\left(400 \mathrm{MHz}, \mathrm{CDCl}_{3}\right) \delta 4.51-4.41(\mathrm{~m}, 4 \mathrm{H}), 3.82(\mathrm{dd}, J=6.0,4.0 \mathrm{~Hz}, 4 \mathrm{H}), 3.71-3.59(\mathrm{~m}$, $8 \mathrm{H})$.

Compound 19. To a solution of cyclic sulfate 6 (10.0 g, $39.0 \mathrm{mmol})$ in DMF (200 mL) was added sodium azide $(3.8 \mathrm{~g}, 58.5 \mathrm{mmol})$ and the resulting mixture was stirred at 80 ${ }^{\circ} \mathrm{C}$ for $5 \mathrm{~h}$. After cooling to $\mathrm{rt}$, excess sodium azide was filtered by a pad of Celite. DMF was removed under vacuum and the resulting residue was dissolved in THF (200 mL). Then, water $(2.1 \mathrm{~mL}, 117.0 \mathrm{mmol})$ and $\mathrm{H}_{2} \mathrm{SO}_{4}(7.2 \mathrm{~mL}, 58.5 \mathrm{mmol})$ were added and the resulting mixture was refluxed for $1 \mathrm{~h}$. The reaction was neutralized with saturated $\mathrm{NaHCO}_{3}$ solution $(100 \mathrm{~mL})$ and extracted with DCM $(100 \mathrm{~mL}$, four times). The organic layers were combined, dried over anhydrous $\mathrm{Na}_{2} \mathrm{SO}_{4}$, concentrated under vacuum, and purified by flash chromatography on silica gel with EtOAc/PE (1/2) as eluents to give 19 (9.7 g, 94\% yield) as light yellow oil. ${ }^{1} \mathrm{H}$ NMR (400 MHz, $\left.\mathrm{CDCl}_{3}\right) \delta 3.85-3.50(\mathrm{~m}$, $14 \mathrm{H}), 3.38(\mathrm{t}, J=5.0 \mathrm{~Hz}, 2 \mathrm{H})$.

Compound 20. Under an atmosphere of Ar, to a suspension of $\mathrm{NaH}(1.1 \mathrm{~g}, 60 \%$ in mineral oil, $28.5 \mathrm{mmol})$ in dry THF (50 mL) was added a solution of compound 19 (5.0 $\mathrm{g}, 19.0 \mathrm{mmol})$ in $\mathrm{THF}(30 \mathrm{~mL})$ at $0^{\circ} \mathrm{C}$ and the resulting mixture was stirred for $30 \mathrm{mins}$ at this temperature. Then a solution of cyclic sulfate $\mathbf{6}(5.84 \mathrm{~g}, 22.8 \mathrm{mmol})$ in THF (20 
$\mathrm{mL})$ was added and the resulting mixture was stirred for $12 \mathrm{~h}$ at $\mathrm{rt}$. Water $(1.0 \mathrm{~mL}, 57.0$ mmol) and $\mathrm{H}_{2} \mathrm{SO}_{4}(3.5 \mathrm{~mL}, 28.5 \mathrm{mmol})$ were added and the resulting mixture was refluxed for $1 \mathrm{~h}$. The reaction was neutralized with saturated $\mathrm{NaHCO}_{3}$ solution (100 $\mathrm{mL})$ and extracted with DCM (100 mL, four times). The organic layers were combined, dried over anhydrous $\mathrm{Na}_{2} \mathrm{SO}_{4}$, concentrated under vacuum, and purified by flash chromatography on silica gel with DCM/MeOH (30/1) as eluents to give 20 (6.8 g, 91\% yield) as light yellow oil. ${ }^{1} \mathrm{H}$ NMR $\left(400 \mathrm{MHz}, \mathrm{CDCl}_{3}\right) \delta 3.67-3.53(\mathrm{~m}, 30 \mathrm{H}), 3.38(\mathrm{t}$, $J=5.0 \mathrm{~Hz}, 2 \mathrm{H})$.

Compound 21 was prepared from 20 by following the same procedure for 20 as light yellow oil (9.8 g, 90\% yield). ${ }^{1} \mathrm{H}$ NMR (400 MHz, $\left.\mathrm{CDCl}_{3}\right) \delta 3.67-3.53(\mathrm{~m}, 46 \mathrm{H}), 3.39$ (t, $J=5.0 \mathrm{~Hz}, 2 \mathrm{H})$.

Compound 22 was prepared from 21 by following the same procedure for 21 as light yellow oil (13.3 g, 93\% yield). ${ }^{1} \mathrm{H}$ NMR (400 MHz, $\left.\mathrm{CDCl}_{3}\right) \delta 3.67-3.53(\mathrm{~m}, 62 \mathrm{H}), 3.39$ (t, $J=5.0 \mathrm{~Hz}, 2 \mathrm{H})$.

Compound 23 was prepared from 22 by following the same procedure for 22 as light yellow oil (17.4 g, 92\% yield). ${ }^{1} \mathrm{H}$ NMR (400 MHz, $\left.\mathrm{CDCl}_{3}\right) \delta 3.67-3.53(\mathrm{~m}, 78 \mathrm{H}), 3.39$ (t, $J=5.0 \mathrm{~Hz}, 2 \mathrm{H})$.

Compound 24 was prepared from 23 by following the same procedure for 23 as light yellow oil (19.9 g, 89\% yield). ${ }^{1} \mathrm{H}$ NMR (400 MHz, $\left.\mathrm{CDCl}_{3}\right) \delta 3.67-3.53(\mathrm{~m}, 94 \mathrm{H}), 3.39$ (t, $J=5.0 \mathrm{~Hz}, 2 \mathrm{H})$.

Compound 25. Under the atmosphere of Ar, to a suspension of $\mathrm{NaH}(0.73 \mathrm{~g}, 60 \%$ in mineral oil, $18.0 \mathrm{mmol})$ in dry THF $(50 \mathrm{~mL})$ was added a solution of $24(10.0 \mathrm{~g}, 9.0$ $\mathrm{mmol})$ in $\mathrm{THF}(30 \mathrm{~mL})$ at $0^{\circ} \mathrm{C}$ and the mixture was stirred for $60 \mathrm{~min}$ at this temperature. Then tert-butyl bromoacetate $(3.55 \mathrm{~g}, 18.0 \mathrm{mmol})$ was added and the resulting mixture was stirred for $18 \mathrm{~h}$ at $\mathrm{rt}$. The mixture was neutralized with saturated ammonium chloride solution, concentrated under vacuum, and purified by flash chromatograph on silica gel with DCM/MeOH (100/3) to give 25 (5.84 g, 53\% yield) as yellow oil. ${ }^{1} \mathrm{H}$ NMR (400 MHz, $\left.\mathrm{CDCl}_{3}\right) \delta 4.01(\mathrm{~s}, 2 \mathrm{H}), 3.75-3.56(\mathrm{~m}, 92 \mathrm{H}), 3.41-3.35(\mathrm{~m}, 2 \mathrm{H}), 2.01$ (s, 2H), $1.46(\mathrm{~s}, 9 \mathrm{H})$.

Compound 26. Compound 25 (7.1 g, $5.8 \mathrm{mmol})$ was dissolved in THF (50 mL) and 
then triphenylphosphine $(2.3 \mathrm{~g}, 8.7 \mathrm{mmol})$ was added, the resulting mixture was stirred for $4 \mathrm{~h}$ at $40^{\circ} \mathrm{C} . \mathrm{H}_{2} \mathrm{O}(0.52 \mathrm{~mL}, 29.2 \mathrm{mmol})$ was then added to the reaction mixture and the mixture was stirred for an additional hour. The reaction mixture was concentrated under vacuum and the residue was dissolved in $\mathrm{H}_{2} \mathrm{O}(100 \mathrm{~mL})$ and washed with diethyl ether $(10 \mathrm{~mL})$ three times. Then the aqueous layer was extracted with DCM (300 mL, 3 times). The combined organic layer was concentrated under vacuum. The residue was dissolved in THF (40 mL) and added to a mixture of saturated $\mathrm{NaHCO}_{3}(0.98 \mathrm{~g}, 11.6$ mmol in $10 \mathrm{~mL} \mathrm{H}_{2} \mathrm{O}$ ) at $0^{\circ} \mathrm{C}$. The reaction mixture was then slowly added a solution of 9-fluorenylmethyl chloroformate $(2.25 \mathrm{~g}, 8.7 \mathrm{mmol})$ in THF $(10 \mathrm{~mL})$ over $1 \mathrm{~h}$. The residue was stirred at $\mathrm{rt}$ for another $4 \mathrm{~h}$. The reaction mixture was concentrated under vacuum, purified by chromatography on silica gel with DCM/MeOH (100/3) to give 26 (5.7 g, 69\% yield) as light yellow oil. ${ }^{1} \mathrm{H}$ NMR (400 MHz, $\left.\mathrm{CDCl}_{3}\right) \delta 7.75(\mathrm{~d}, J=7.5$ $\mathrm{Hz}, 2 \mathrm{H}), 7.60(\mathrm{~d}, J=7.4 \mathrm{~Hz}, 2 \mathrm{H}), 7.39$ (t, $J=7.4 \mathrm{~Hz}, 2 \mathrm{H}), 7.30(\mathrm{t}, J=7.4 \mathrm{~Hz}, 2 \mathrm{H}), 4.38$ $(\mathrm{d}, J=7.0 \mathrm{~Hz}, 2 \mathrm{H}), 4.22(\mathrm{~m}, 1 \mathrm{H}), 3.67-3.58(\mathrm{~m}, 96 \mathrm{H}), 3.42-3.35(\mathrm{~m}, 2 \mathrm{H}), 1.46(\mathrm{~s}, 9 \mathrm{H})$.

Compound 5. A solution of compound 26 (5.73 g, $4.1 \mathrm{mmol})$, anisole (0.88 mL, 8.2 mmol) and TFA $(6.0 \mathrm{~mL})$ in DCM $(40 \mathrm{~mL})$ was stirred at $30^{\circ} \mathrm{C}$ overnight. After concentrated under vacuum, the residue was dissolved in water $(50 \mathrm{~mL})$ and washed with diethyl ether $(10 \mathrm{~mL})$. The organic layer was discarded and the aqueous layer was extracted with DCM (200 mL, 3 times). The combined organic layer was dried over anhydrous $\mathrm{Na}_{2} \mathrm{SO}_{4}$, concentrated under vacuum to give 5 ( $5.0 \mathrm{~g}, 91 \%$ yield) as colorless oil. ${ }^{1} \mathrm{H}$ NMR (400 MHz, $\left.\mathrm{CDCl}_{3}\right) \delta 7.76(\mathrm{~d}, J=7.5 \mathrm{~Hz}, 2 \mathrm{H}), 7.61(\mathrm{~d}, J=7.4 \mathrm{~Hz}, 2 \mathrm{H})$, 7.39 (t, $J=7.4 \mathrm{~Hz}, 2 \mathrm{H}), 7.32(\mathrm{~d}, J=7.4 \mathrm{~Hz}, 2 \mathrm{H}), 4.38(\mathrm{~d}, J=7.0 \mathrm{~Hz}, 2 \mathrm{H}), 4.22$ (t, $J=$ $7.0 \mathrm{~Hz}, 1 \mathrm{H}), 4.03(\mathrm{~s}, 2 \mathrm{H}), 3.72-3.57(\mathrm{~m}, 96 \mathrm{H})$.

Agent 1. MS (MALDI) m/z calcd for $\mathrm{C}_{264} \mathrm{H}_{509} \mathrm{~N}_{7} \mathrm{NaO}_{128}{ }^{+}[\mathrm{M}+\mathrm{Na}]^{+} 5849.3$, found 5849.5 .

Agent 2. MS (MALDI) m/z calcd for $\mathrm{C}_{514} \mathrm{H}_{1004} \mathrm{~N}_{12} \mathrm{NaO}_{253}{ }^{+}[\mathrm{M}+\mathrm{Na}]^{+}$11417.6, found 11420.0

Peptide 7. ${ }^{1} \mathrm{H}$ NMR (400 MHz, $\left.\mathrm{CD}_{3} \mathrm{OD}\right) \delta$ 7.51-6.98 (m, 5H), 4.67-4.53 (m, 1H), 4.38 $(\mathrm{t}, J=6.3 \mathrm{~Hz}, 1 \mathrm{H}), 3.82(\mathrm{dd}, J=42.3,17.0 \mathrm{~Hz}, 2 \mathrm{H}), 3.12(\mathrm{~d}, J=6.3 \mathrm{~Hz}, 1 \mathrm{H}), 2.99-2.77$ (m, 3H), 1.92 (s, 3H). ${ }^{13} \mathrm{C}$ NMR (100 MHz, DMSO) $\delta 171.9,170.9$, 169.8, 169.8, 137.9, 
129.2, 128.1, 126.3, 55.3, 54.3, 44.2, 42.0, 37.2, 25.9, 22.4. HRMS (ESI) calcd for $\mathrm{C}_{16} \mathrm{H}_{23} \mathrm{~N}_{4} \mathrm{O}_{4} \mathrm{~S}^{+}[\mathrm{M}+\mathrm{H}]^{+}$367.1435, found 367.1458.

GCF-S-M-PEG ${ }_{5.8 k} 8$ MS (MALDI) m/z calcd for $\mathrm{C}_{280} \mathrm{H}_{531} \mathrm{~N}_{11} \mathrm{NaO}_{132} \mathrm{~S}^{+}[\mathrm{M}+\mathrm{Na}]^{+}$ 6215.5 , found 6218.0 .

Peptide 10. ${ }^{1} \mathrm{H}$ NMR (400 MHz, $\left.\mathrm{CD}_{3} \mathrm{OD}\right) \delta$ 7.48-7.07 (m, 5H), $4.54(\mathrm{dd}, J=8.5,6.6$ $\mathrm{Hz}, 1 \mathrm{H}), 4.27$ (dd, $J=8.8,5.2 \mathrm{~Hz}, 1 \mathrm{H}), 3.79(\mathrm{q}, J=17.0 \mathrm{~Hz}, 2 \mathrm{H}), 3.12(\mathrm{~d}, J=6.5 \mathrm{~Hz}$, $1 \mathrm{H}), 2.91(\mathrm{t}, J=7.5 \mathrm{~Hz}, 3 \mathrm{H}), 2.09-1.80(\mathrm{~m}, 4 \mathrm{H}), 1.75-1.33(\mathrm{~m}, 5 \mathrm{H}) .{ }^{13} \mathrm{C} \mathrm{NMR}(100$ $\left.\mathrm{MHz}, \mathrm{D}_{2} \mathrm{O}\right) \delta 173.0,172.8,172.3,172.3,136.9,128.9,128.2,126.5,55.3,53.3,41.7$, 39.1, 37.0, 30.3, 26.5, 22.2, 21.0. HRMS (ESI) calcd for $\mathrm{C}_{19} \mathrm{H}_{30} \mathrm{~N}_{5} \mathrm{O}_{4}{ }^{+}[\mathrm{M}+\mathrm{H}]^{+}$ 392.2292, found 392.2341.

GKF-NH-M-PEG5.8k 11 MS (MALDI) m/z calcd for $\mathrm{C}_{283} \mathrm{H}_{538} \mathrm{~N}_{12} \mathrm{NaO}_{132}{ }^{+}$ $[\mathrm{M}+\mathrm{Na}]^{+} 6240.6$, found 6241.9

\section{Stability study of agents 1-4 in rat plasma.}

Agents 1-4 were treated with sodium thioglycolate for $24 \mathrm{~h}$ at room temperature to remove the reactive maleimide group, which were purified by ultrafiltration and then freeze-drying.

The in vitro stability studies of $\mathbf{1 - 4}$ were conducted in SD rat plasma. In brief, 10.0 mg of 1-4 were incubated with $400 \mu \mathrm{L}$ of rat plasma at $37^{\circ} \mathrm{C}$ for $72 \mathrm{~h}$ with gentle stirring, respectively. At 1, 3, 6, 12, 24, 36, 48, 60, $72 \mathrm{~h}$, a sample $(20 \mu \mathrm{L})$ was collected and mixed with $1.0 \mathrm{~mL}$ of methanol. The mixture was filtered and analyzed by HPLC.

\section{Biocompatibility assay of agents 1-4}

The biocompatibility of agents 1-4 were evaluated in L929 cells by MTT assay. Briefly, L929 cells were seeded into a 96-well plate in $100 \mu \mathrm{L}$ of alpha-MEM with $10 \%$ FBS and $1 \%$ streptomycin double antibody. The cells were cultured in $5 \% \mathrm{CO}_{2}$ for $24 \mathrm{~h}$ at $37^{\circ} \mathrm{C}$. Then the cells were incubated with $1-4$, respectively, for 1 day at $37^{\circ} \mathrm{C}$. The concentrations ranged from $25 \mu \mathrm{M}$ to $400 \mu \mathrm{M}$. Cells treated with only media were used as control. After incubation, MTT stock solution 20 $\mu \mathrm{L}(1 \mathrm{mg} / \mathrm{mL}$ in PBS) was added to each well and incubated for another $4 \mathrm{~h}$. And then the media was replaced by $100 \mu \mathrm{L}$ of DMSO to dissolve the formazan blue crystal. The relative cell viability (\%) was determined by comparing the 
absorbance of each well at $490 \mathrm{~nm}$ with control wells without addition of agents 1-4 using the microplate reader (Bio Tek Instruments, USA).

\section{Determination of $\boldsymbol{n}$-octanol/water partition coefficients}

The $\log \mathrm{P}$ values of 7-12 were measured following shake-flask method. In brief, 712 were dissolved in distilled water saturated with $n$-octanol, respectively. Then $1 \mathrm{~mL}$ of the solution was mixed with an equal volume of $n$-octanol saturated with distilled water on a vortex device. After shaking the mixture for $12 \mathrm{~h}$, water phase and $n$-octanol phase were separated by centrifugation. Equal-volume samples of the water phase and the starting water solution were subsequently taken and analyzed by HPLC. The peak area was measured at $\lambda=222 \mathrm{~nm}$, and compared with calibration curve to obtain the concentration of the 7-12. $\log P$ values were determined with the formula: $\log \left[\left(\mathrm{C}_{\mathrm{s}^{-}}\right.\right.$ $\left.\mathrm{C}_{\mathrm{w}}\right) / \mathrm{C}_{\mathrm{w}}$, where $\mathrm{C}_{\mathrm{s}}$ and $\mathrm{C}_{\mathrm{w}}$ were the peptide concentrations of the starting water solution and the water phase, respectively.

\section{Purity identification of 15-18}

Reaction mixtures and fractions from DEAE Focurose 6FF column were analyzed by SDS-PAGE. A discontinuous system was employed. The gels were consisted of a separating gel (containing 10\% (w/v) acrylamide) and a stacking gel (containing 5\% (w/v) acrylamide). Samples in loading buffer were incubated at $100^{\circ} \mathrm{C}$ for $5 \mathrm{~min}$ before electrophoresis. Electrophoresis was programmed with $80 \mathrm{~V}$ in stacking gel and $125 \mathrm{~V}$ in the separation gel. Coomassie brilliant blue was used to detect the proteins.

\section{PEGylated proteins structure Analysis by Far-UV CD Measurement}

The secondary structure of proteins $\mathbf{1 3}, \mathbf{1 4}$ and 15-18 were recorded in the far UV region (190-260 nm) on a Chirascan Plus at room temperature. The samples were dissolved in $50 \mathrm{mM}$ phosphate buffer of $\mathrm{pH} 7.4$ at a concentration of $3 \mu \mathrm{M}$. The band width is $1 \mathrm{~nm}$ and time-per-point is $1 \mathrm{~s}$.

\section{Hydrodynamic Radius Determination of proteins by Dynamic Light Scattering} The hydrodynamic radius $\left(R_{\mathrm{h}}\right)$ of proteins 13-18 were determined by dynamic light scattering (DLS) on a Nano ZS 90 at room temperature. The samples were dissolved in $50 \mathrm{mM}$ phosphate buffer of $\mathrm{pH} 7.4$ at a concentration of $3 \mu \mathrm{M}$. DLS measurements with 
a linearly polarized gallium arsenide (GaAs) laser ( $\lambda=658 \mathrm{~nm})$, which were conducted at a scattering angle of $99^{\circ}$.

Table S1. DLS of proteins at room temperature

\begin{tabular}{lllllll}
\hline & $\mathbf{1 3}$ & $\mathbf{1 5}$ & $\mathbf{1 7}$ & $\mathbf{1 4}$ & $\mathbf{1 6}$ & $\mathbf{1 8}$ \\
\hline Size $(\mathrm{nm})$ & 8.71 & 31.86 & 31.13 & 8.55 & 31.04 & 29.34 \\
\hline
\end{tabular}
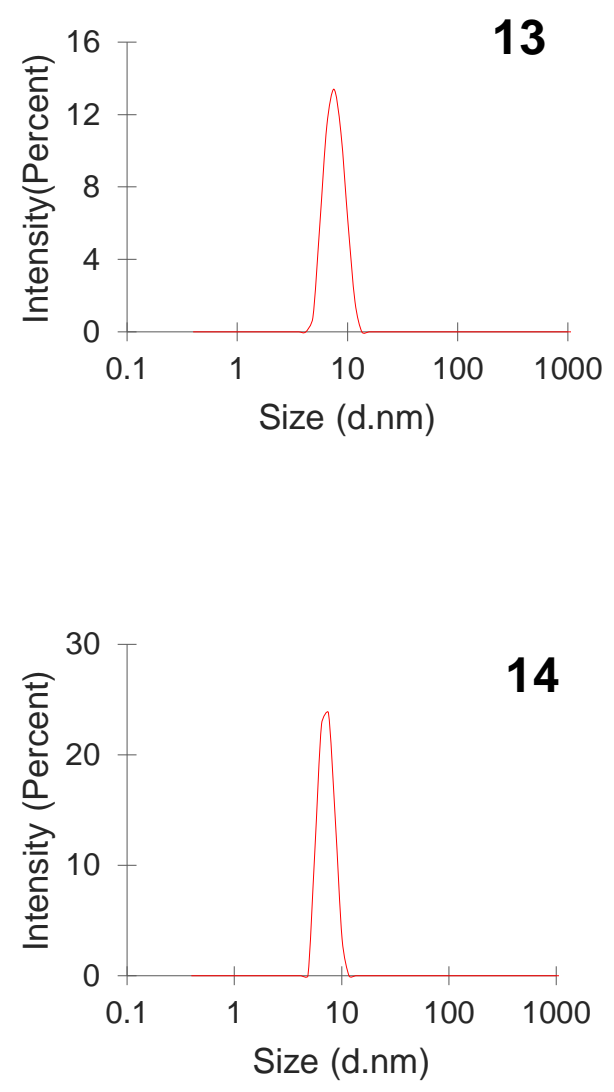

\section{Animal Experiment}

Female SD rats (180-200 g) were purchased from Hubei Experimental Animal Research Center. All experimental protocols in this study were approved by Animal Care and Use Committees at Wuhan University. The animals randomly sorted into 4 treatment groups of 5 rats per group: Group 1 (naive group, PBS, $1 \mathrm{~mL} / \mathrm{kg}$ ), Group 2 (control group, HSA 13, $0.025 \mu \mathrm{mol} / \mathrm{kg}, 1.66 \mathrm{mg} / \mathrm{kg}$ ), Group 3 (HSA-S-M-PEG $11.4 \mathrm{~K}$ 15, $0.025 \mu \mathrm{mol} / \mathrm{kg}, 1.95 \mathrm{mg} / \mathrm{kg}$ ), Group 4 (HSA-S-PEG $10 \mathrm{~K}$ 17, $0.025 \mu \mathrm{mol} / \mathrm{kg}, 1.91 \mathrm{mg} / \mathrm{kg}$ ). Each rat was subcutaneously injected with $0.2 \mathrm{~mL}$ of the corresponding solution on Day 
0, Day 7, Day 14. After the last administration on Day 14, a one-week recovery period set for the research. The rats were exsanguinated. Whole blood was collected into tubes and processed into plasma for $\operatorname{IgG}$ and $\operatorname{IgM}$ measurements. The major organs, including heart, liver, spleen, lung and kidneys, were collected and fixed with paraformaldehyde and cry sectioned for hematoxylin-eosin staining (H\&E). Elisa kits were purchased from Enzyme Biotechnology (Wuhan, China, IgG kit: Capture antibody: anti-rat IgG total monoclonal antibody, Detection antibody: HRP-conjugated anti-rat Ig $(\mathrm{H}+\mathrm{L})$ monoclonal antibody; IgM kit: Capture antibody: anti-rat $\operatorname{IgM}$ monoclonal antibody, Detection antibody: HRP-conjugated anti-rat Ig $(\mathrm{H}+\mathrm{L})$ monoclonal antibody) and the measurements followed the kit instructions.

\section{Reference}

1. Zhu, J.; Xiao, Y.; Zhang, H.; Li, Y.; Yuan, Y.; Yang, Z.; Chen, S.; Zheng, X.; Zhou, X.; Jiang, Z., Biomacromolecules. 2019, 20, 1281-1287. 
10. Copies of ${ }^{1} \mathrm{H}$ NMR, ${ }^{13} \mathrm{C}$ NMR and MS spectra of compounds

Compound 6. ${ }^{1} \mathrm{H}$ NMR (400 MHz, $\mathrm{CDCl}_{3}$ )
20170510-jiengex-15
$\frac{6}{{ }^{1} \mathrm{HNMR}\left(\mathrm{CDCl}_{3}, 400 \mathrm{MHz}\right)}$
$\stackrel{\overbrace{}}{\top}$

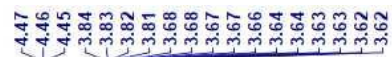

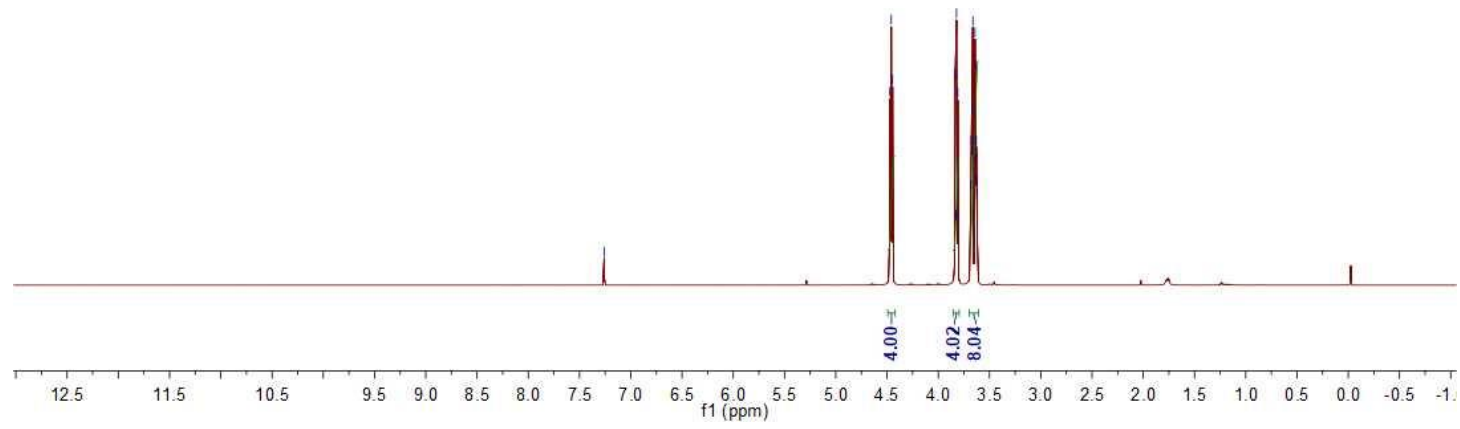

Compound 19. ${ }^{1} \mathrm{H}$ NMR (400 MHz, $\left.\mathrm{CDCl}_{3}\right)$

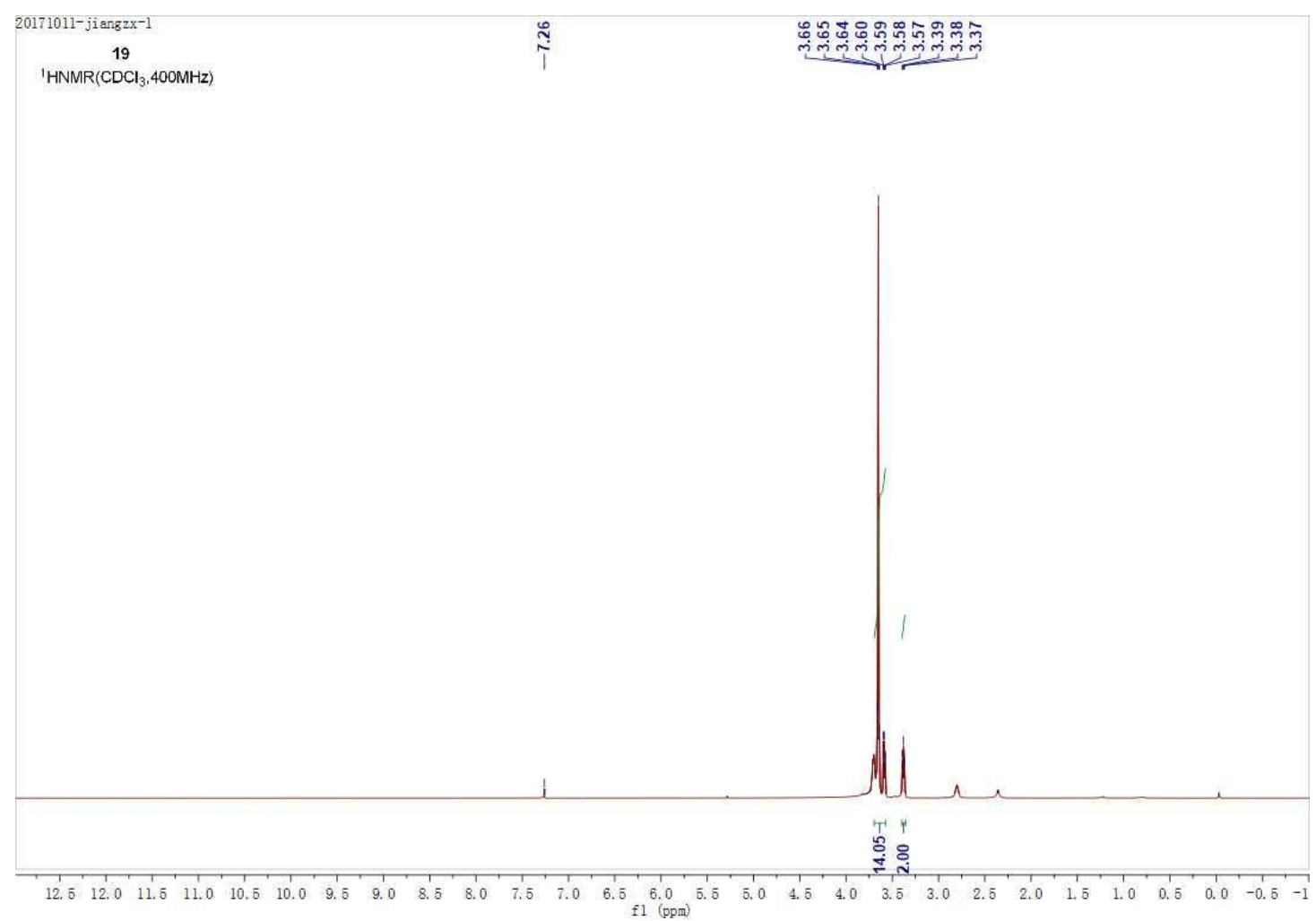


Compound 20. ${ }^{1} \mathrm{H}$ NMR (400 MHz, $\left.\mathrm{CDCl}_{3}\right)$

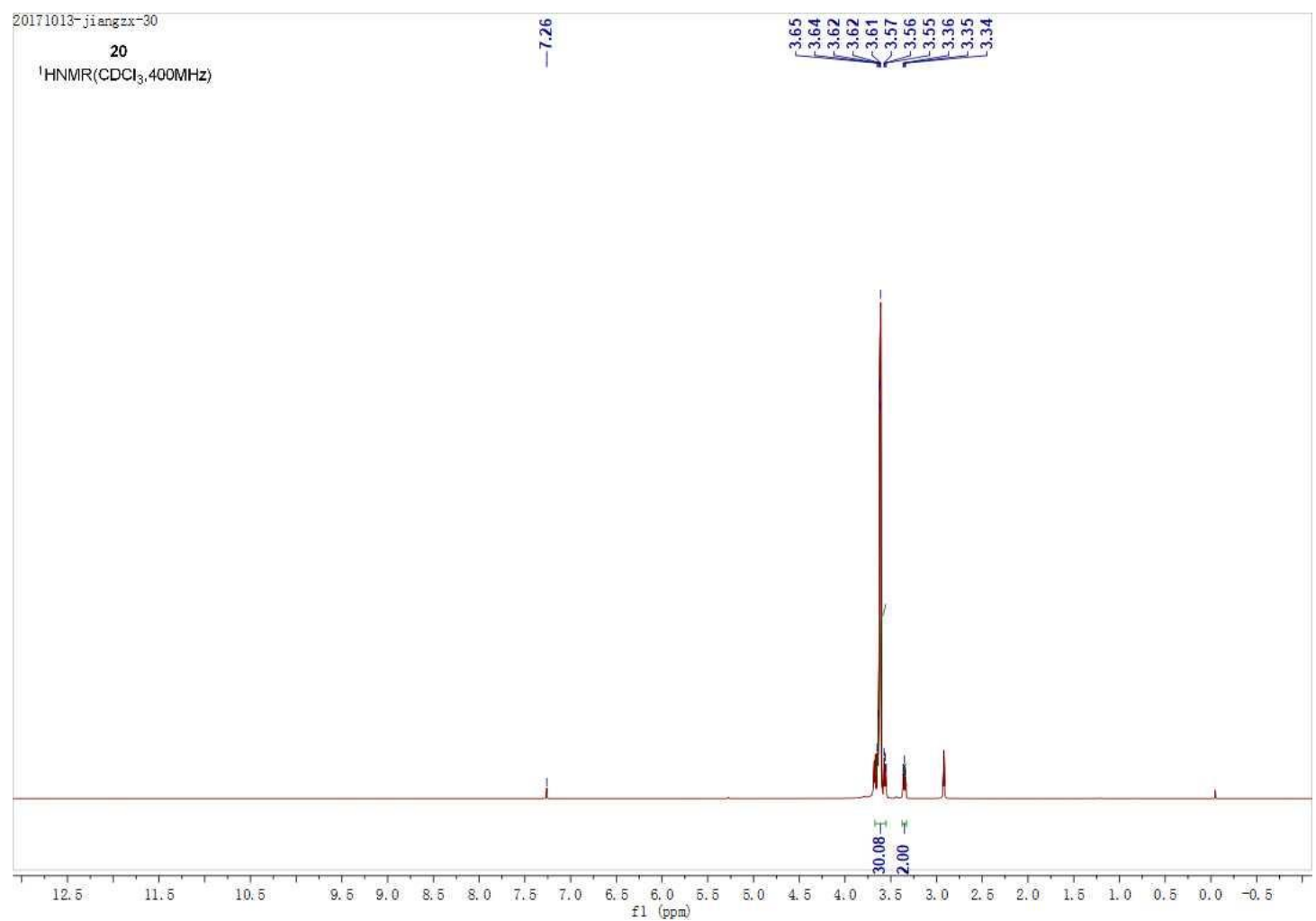

Compound 21. ${ }^{1} \mathrm{H}$ NMR (400 MHz, $\mathrm{CDCl}_{3}$ )

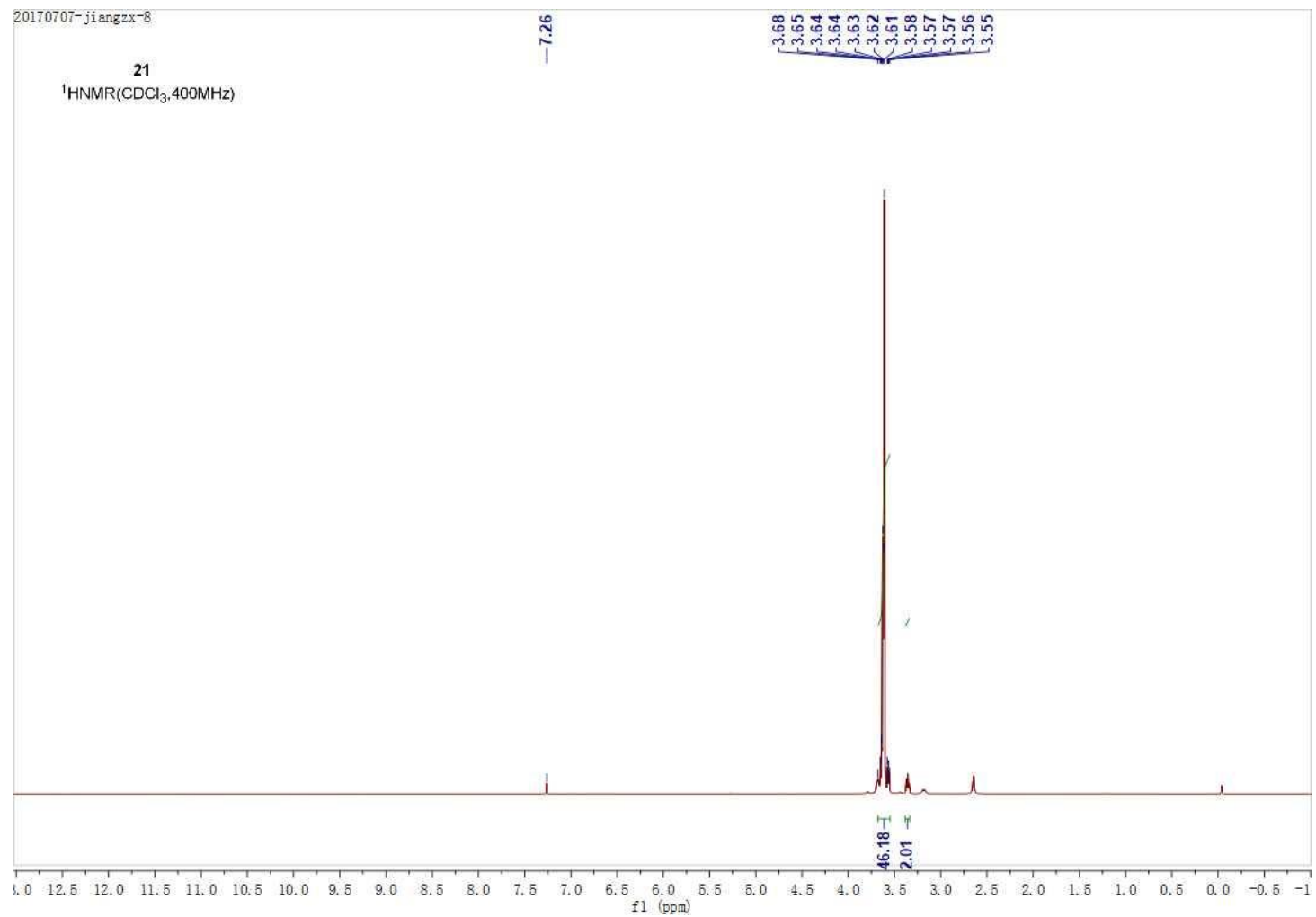


Compound 22. ${ }^{1} \mathrm{H}$ NMR $\left(400 \mathrm{MHz}, \mathrm{CDCl}_{3}\right)$

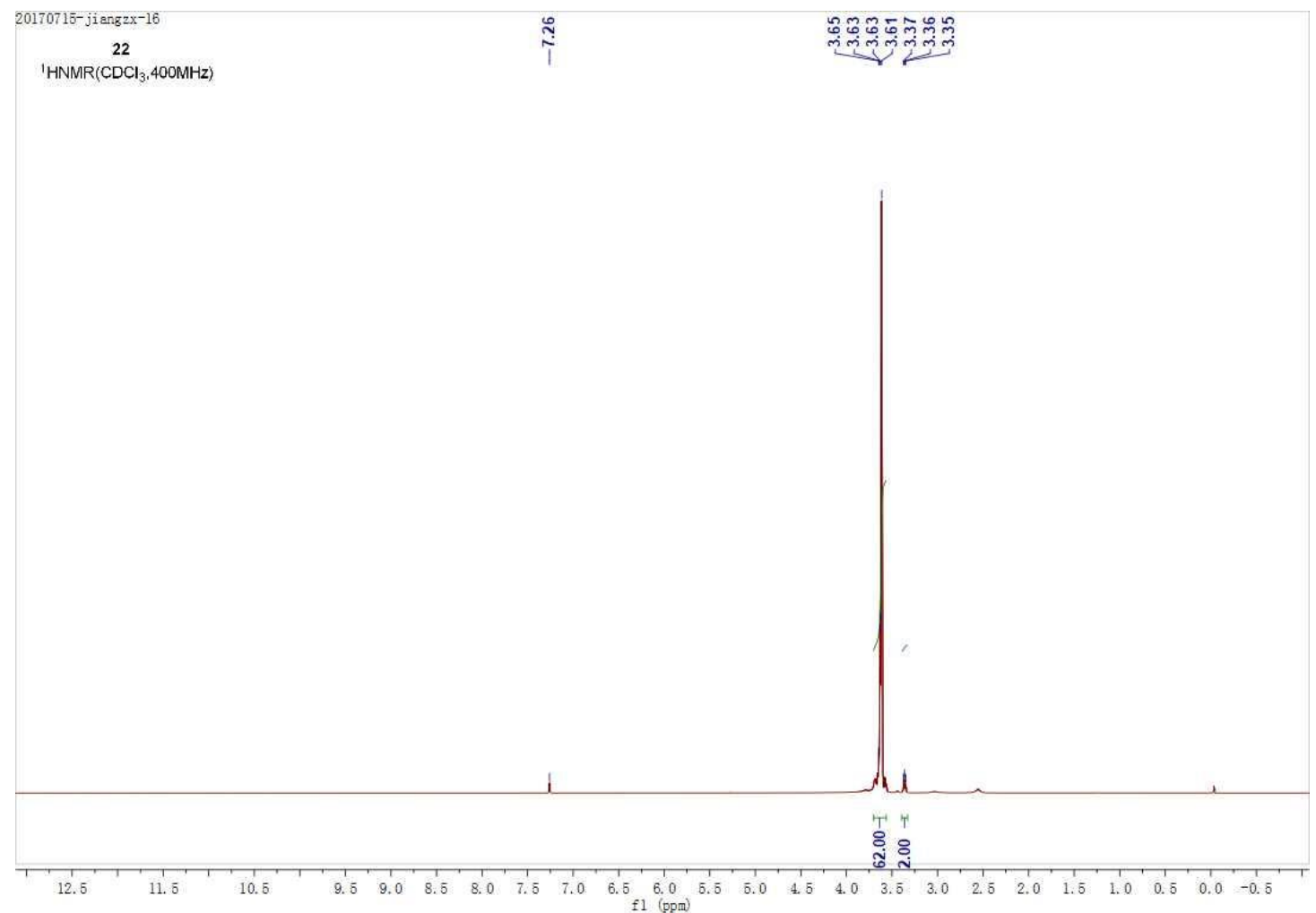

Compound 23. ${ }^{1} \mathrm{H}$ NMR (400 MHz, $\mathrm{CDCl}_{3}$ )

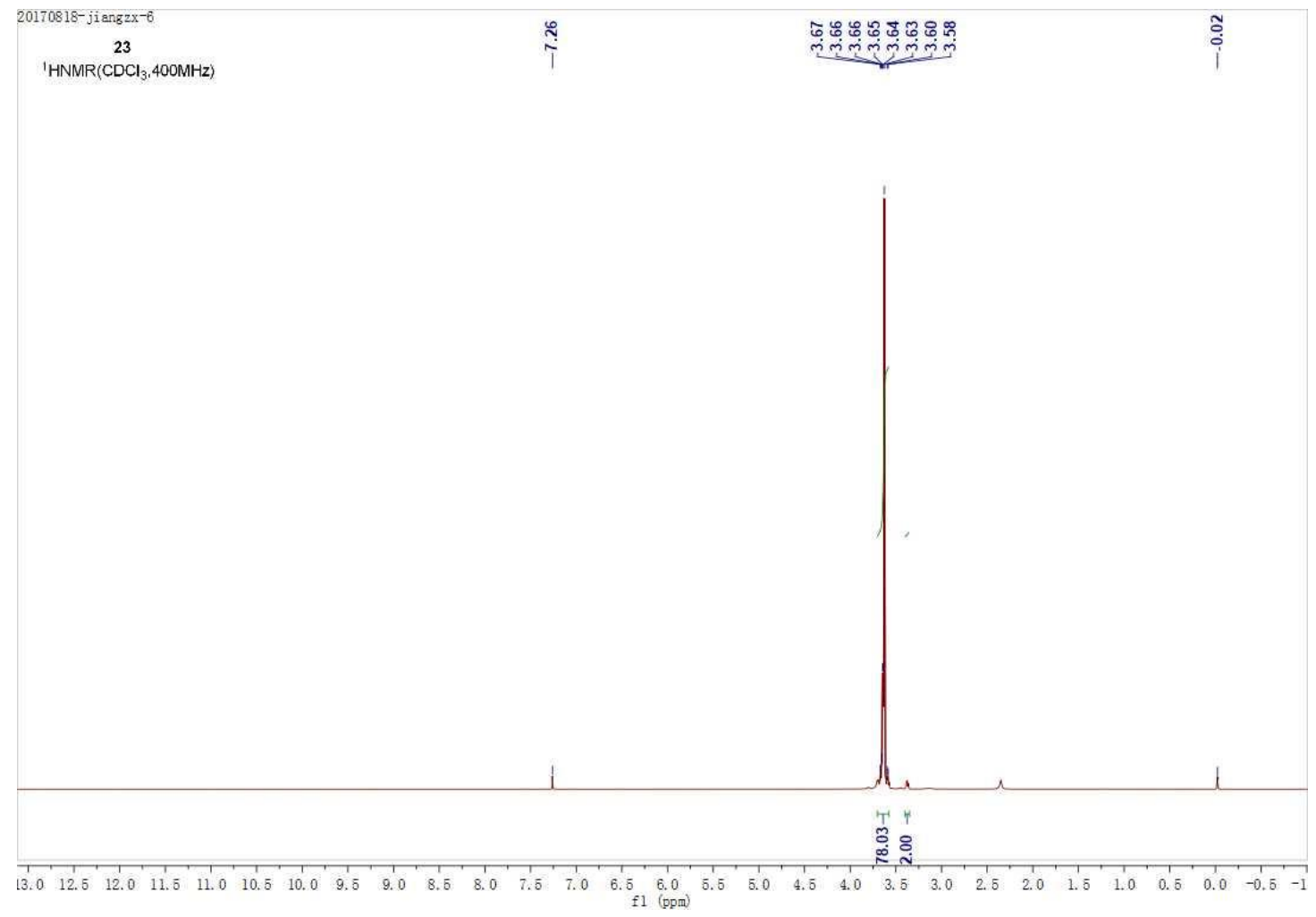


Compound 24. ${ }^{1} \mathrm{H}$ NMR (400 MHz, $\left.\mathrm{CDCl}_{3}\right)$

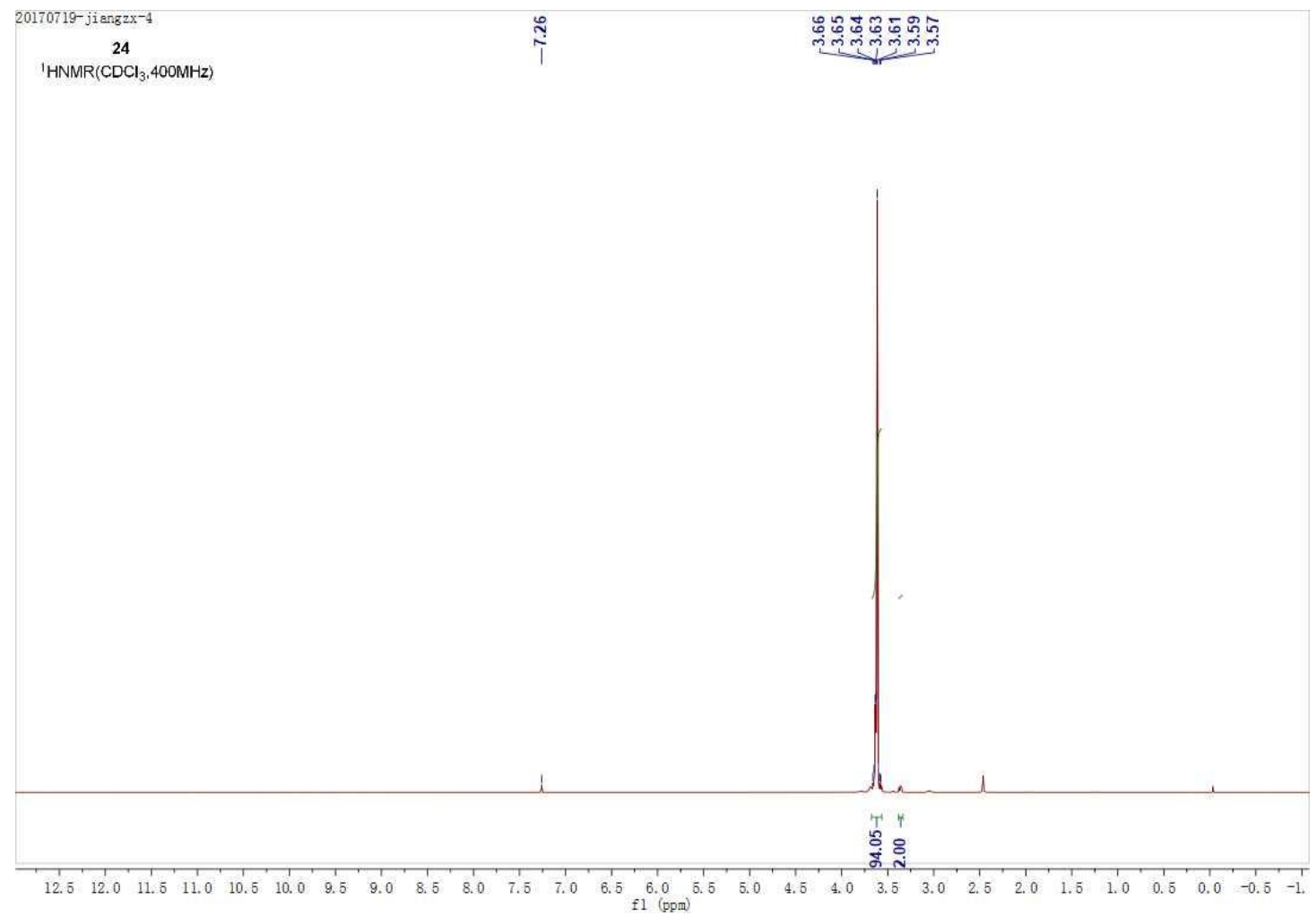

Compound 25. ${ }^{1} \mathrm{H}$ NMR (400 MHz, $\mathrm{CDCl}_{3}$ )

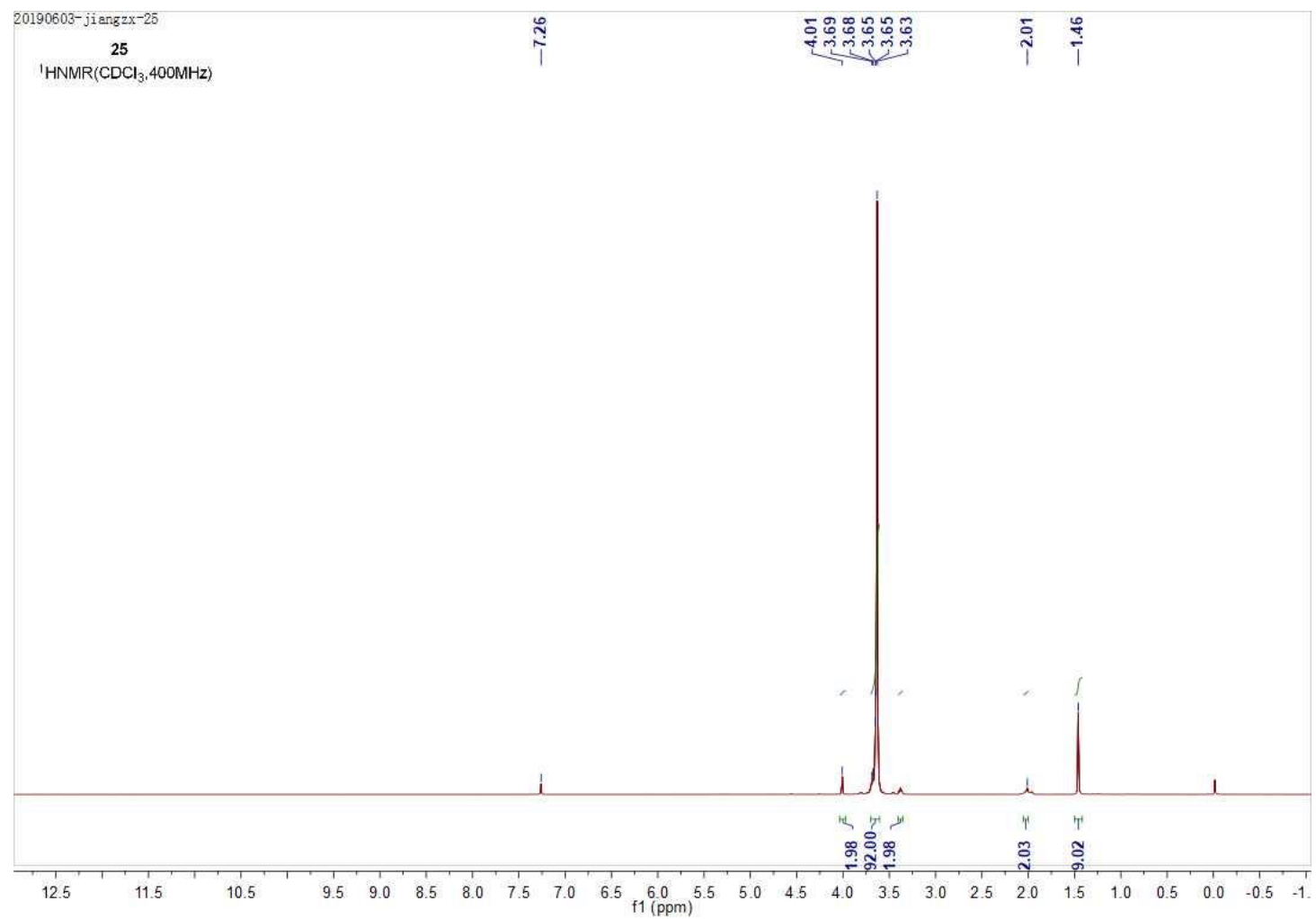


Compound 26. ${ }^{1} \mathrm{H}$ NMR (400 MHz, $\left.\mathrm{CDCl}_{3}\right)$

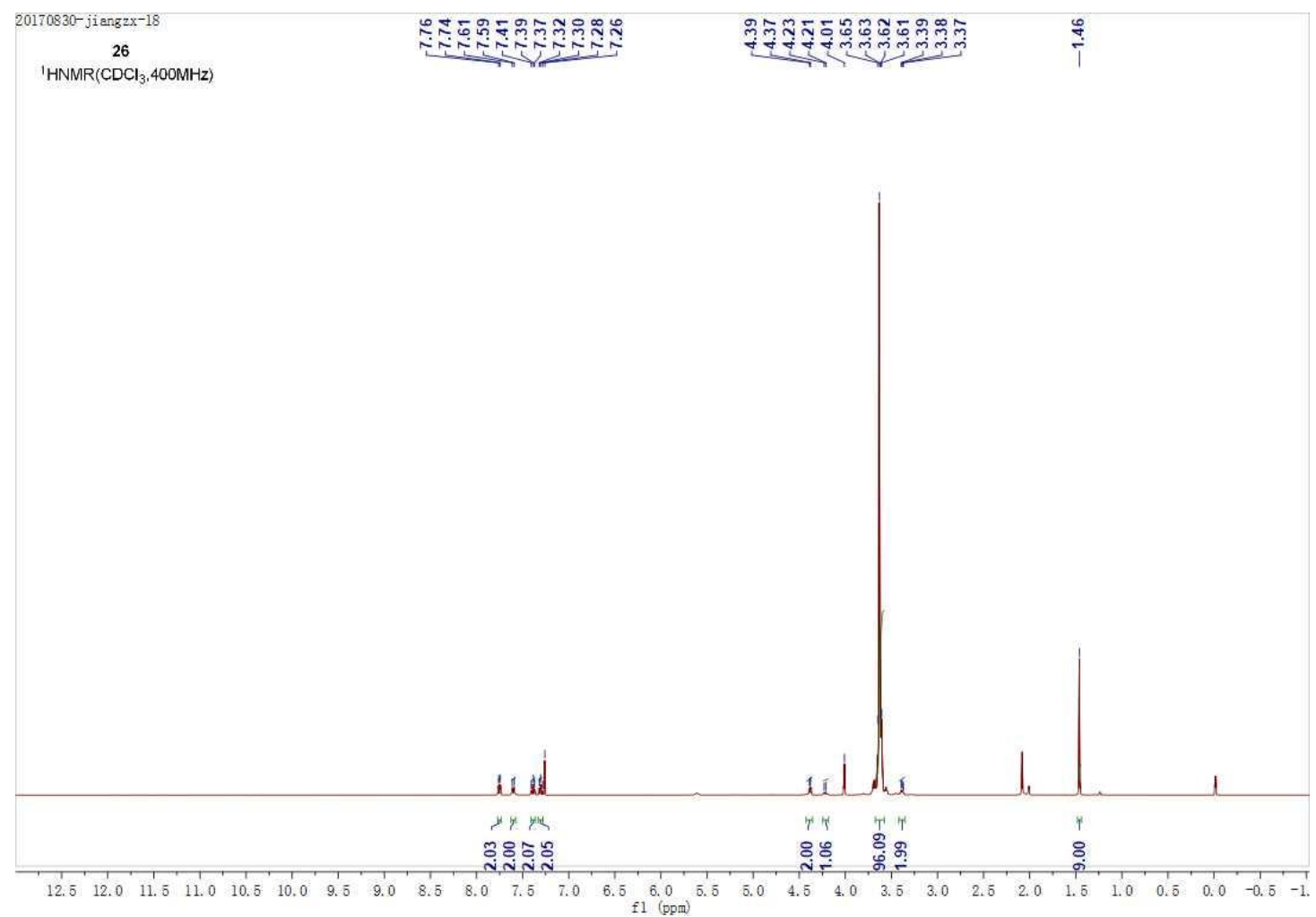

Compound 5. ${ }^{1} \mathrm{H}$ NMR (400 MHz, $\left.\mathrm{CDCl}_{3}\right)$

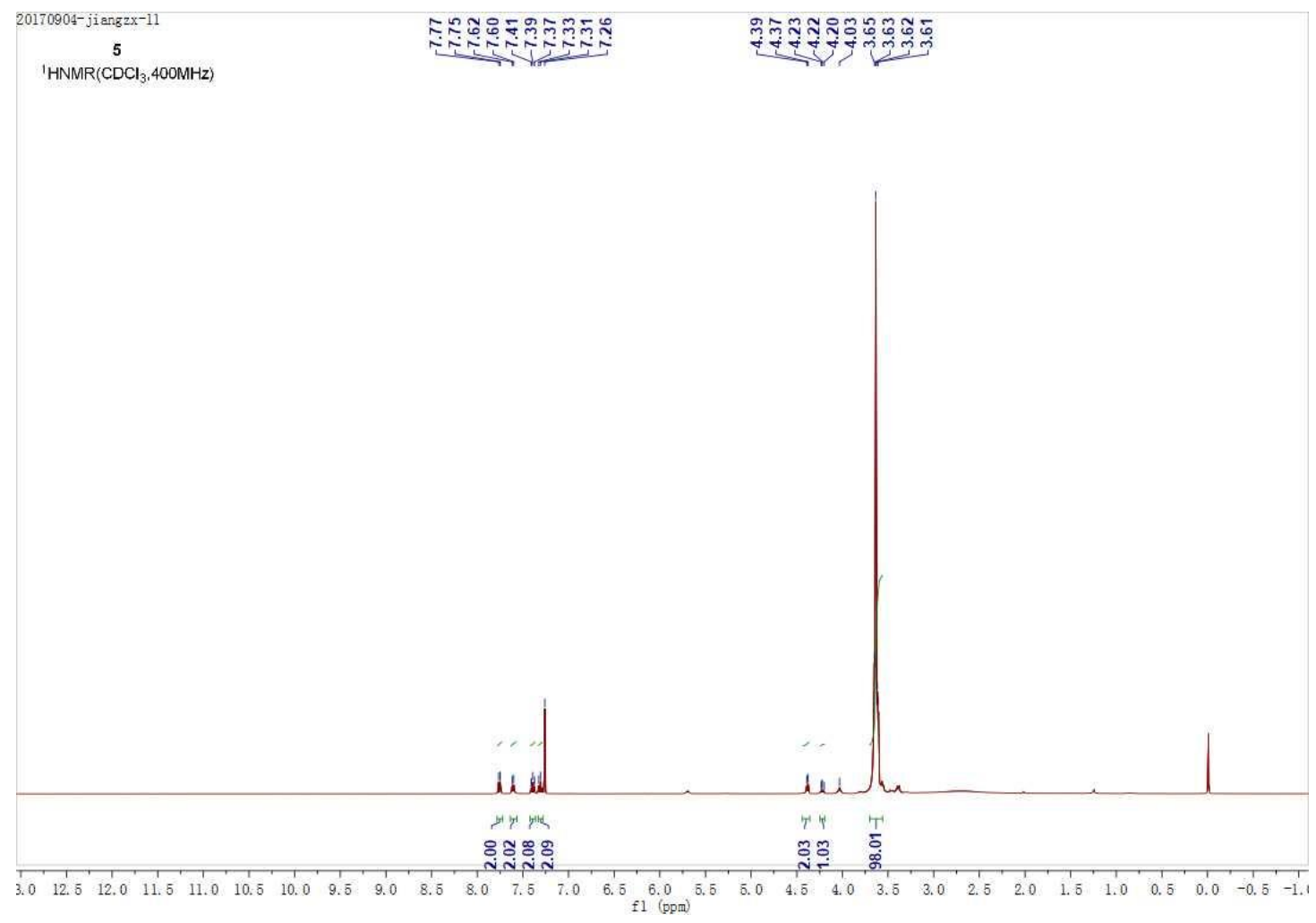


Agent 1 Maldi-Tof mass spectrum

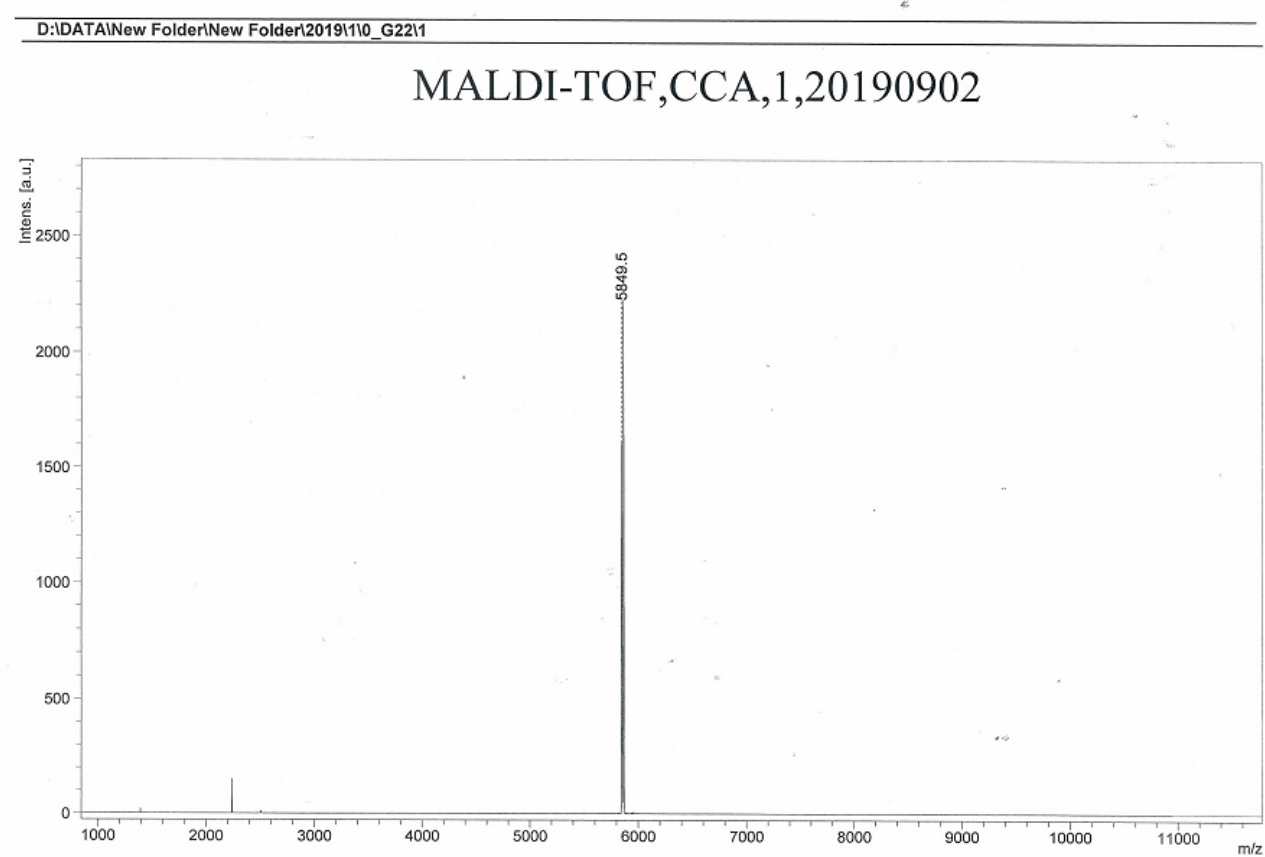

Agent 2 Maldi-Tof mass spectrum

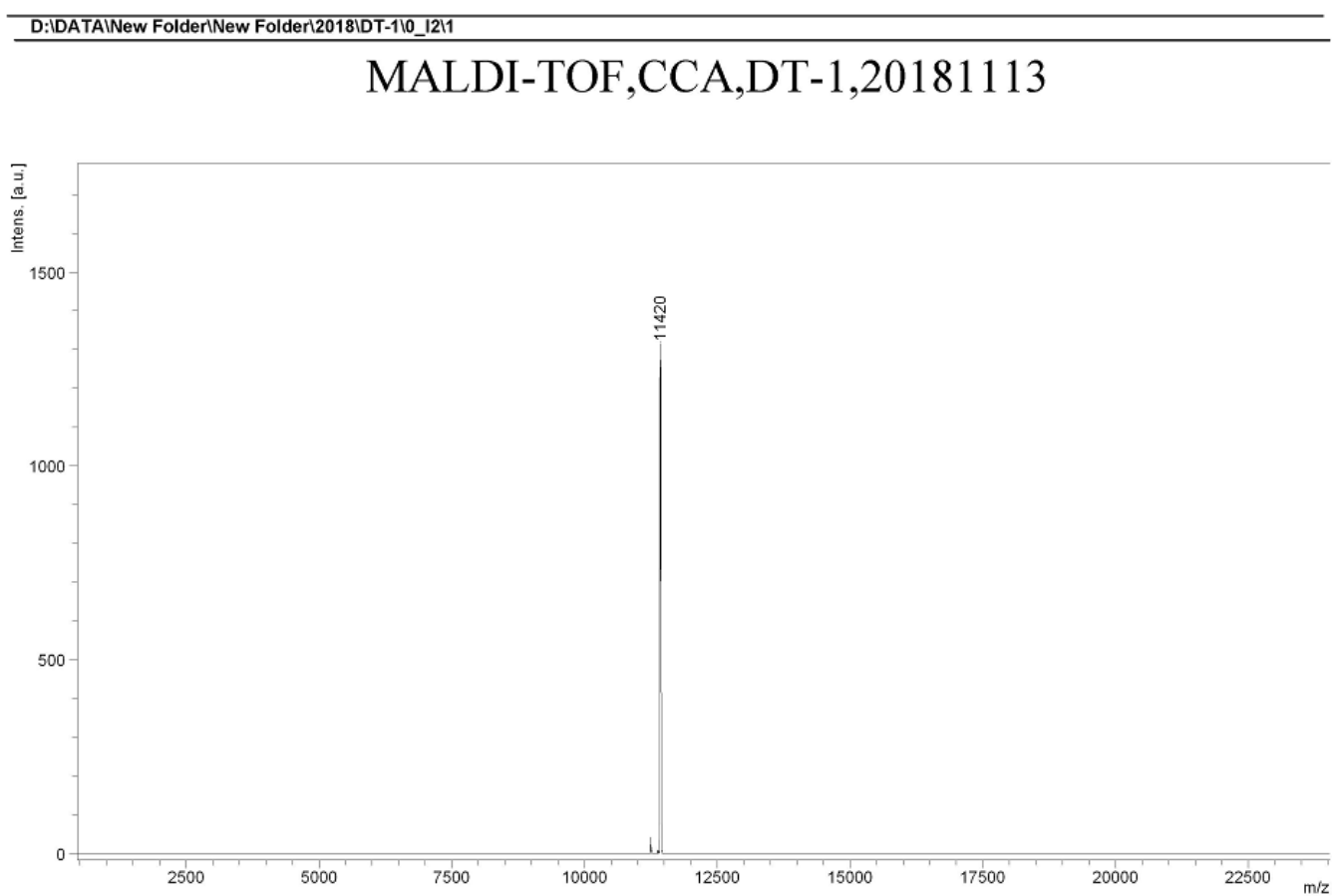


Peptide 7. ${ }^{1} \mathrm{H}$ NMR $\left(400 \mathrm{MHz}, \mathrm{CD}_{3} \mathrm{OH}\right)$

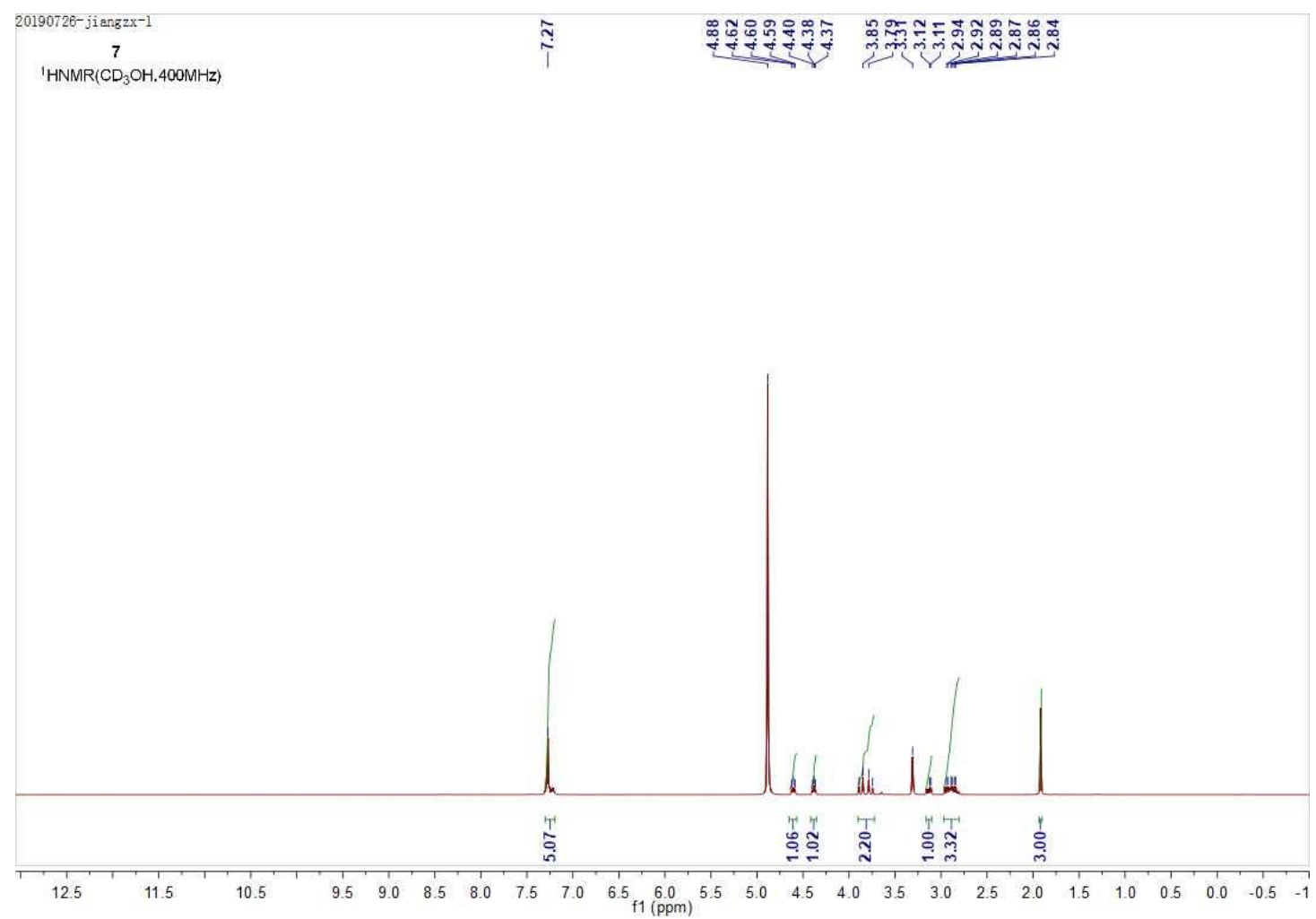

Peptide 7. ${ }^{13} \mathrm{C}$ NMR (100 MHz, $\mathrm{d}_{6}$-DMSO)

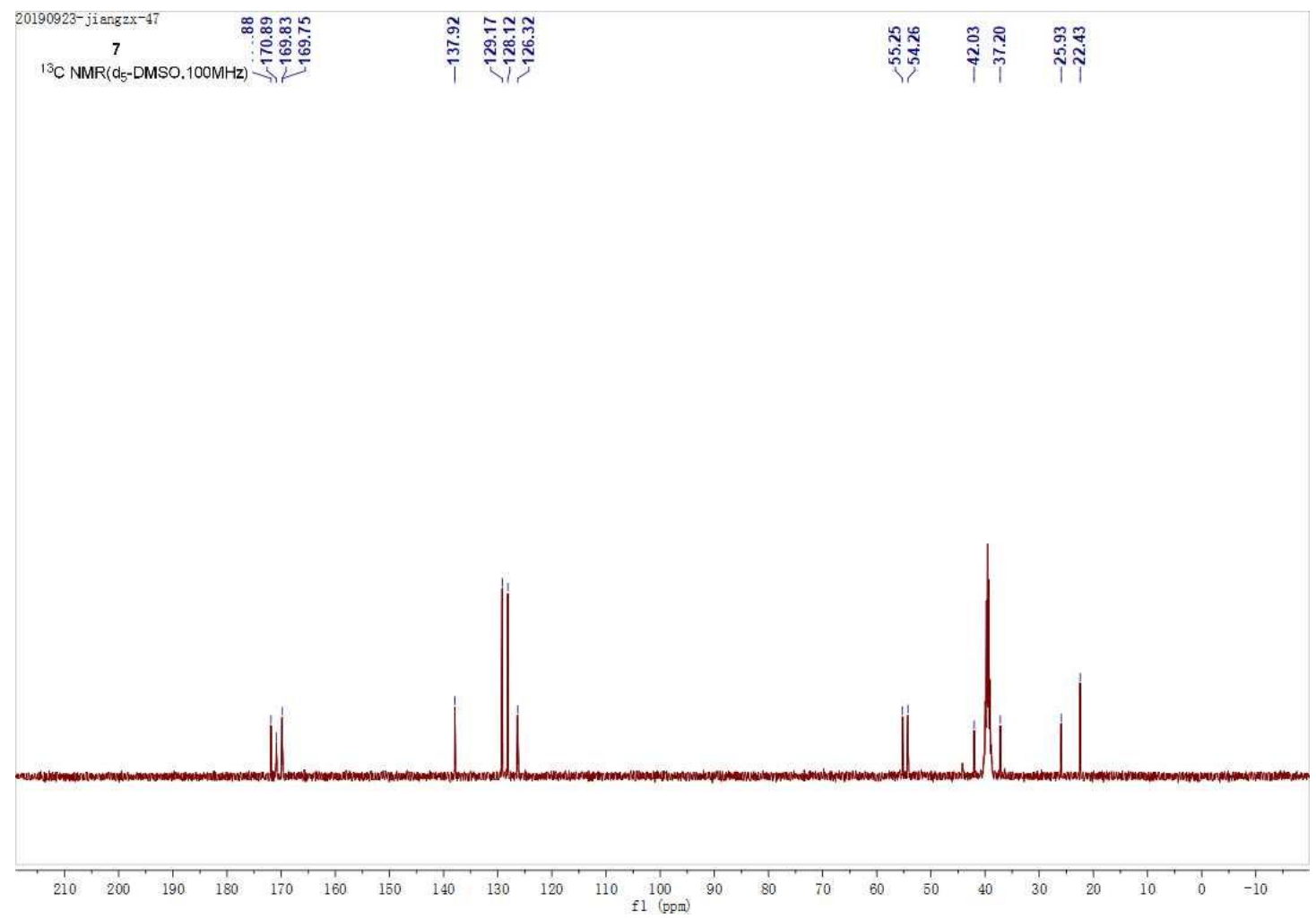




\section{Peptide 7. HRMS (ESI)}

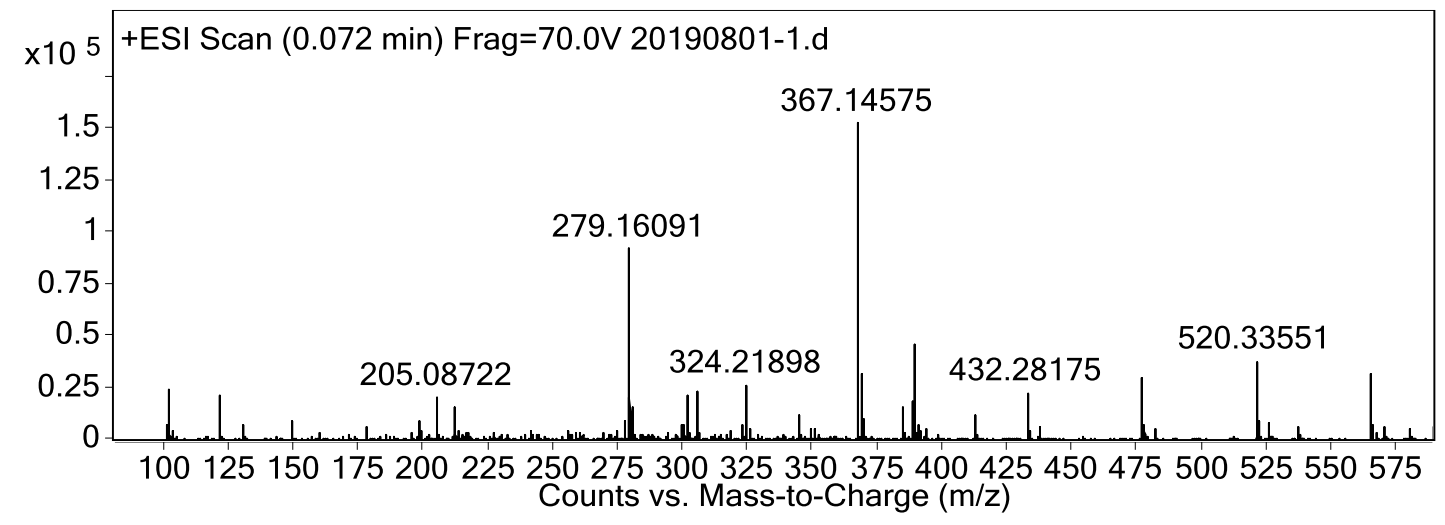

8 Maldi-Tof mass spectrum

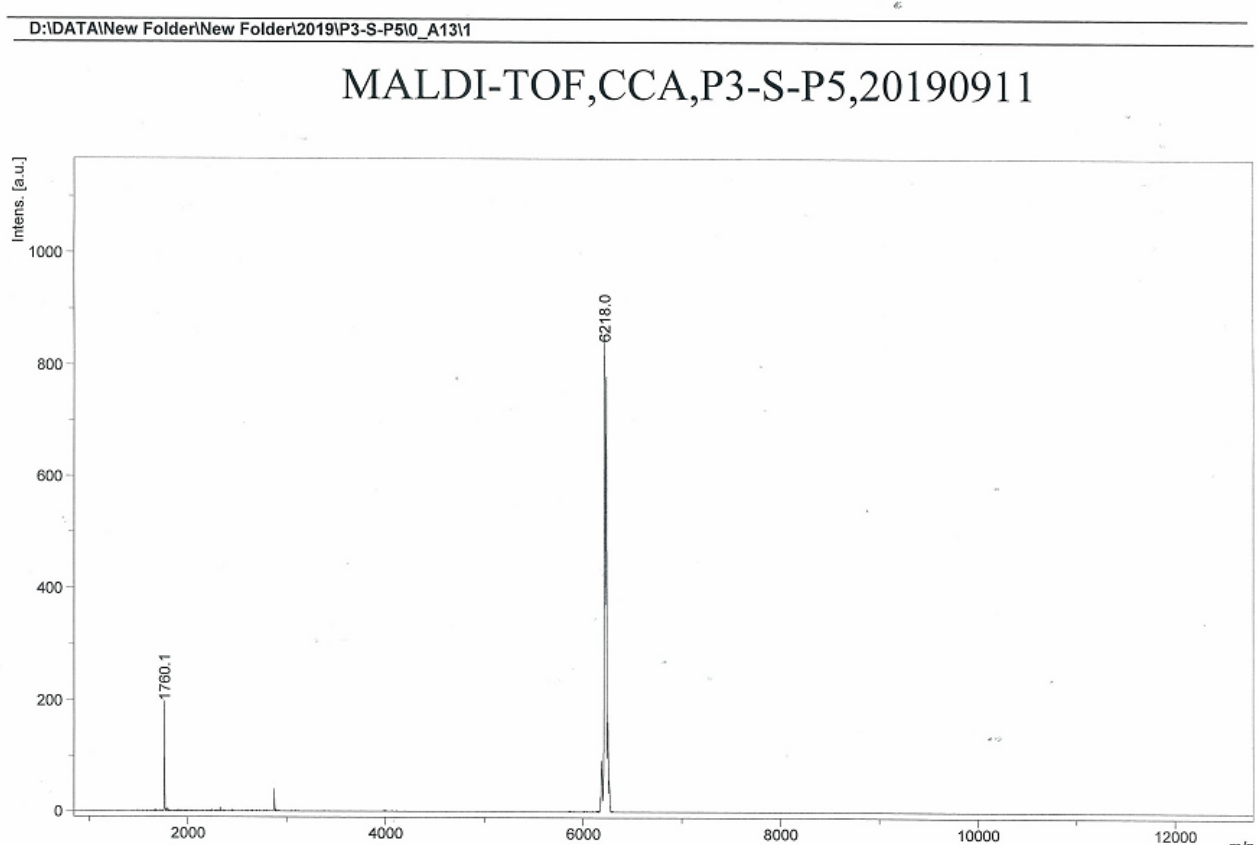


9 Maldi-Tof mass spectrum

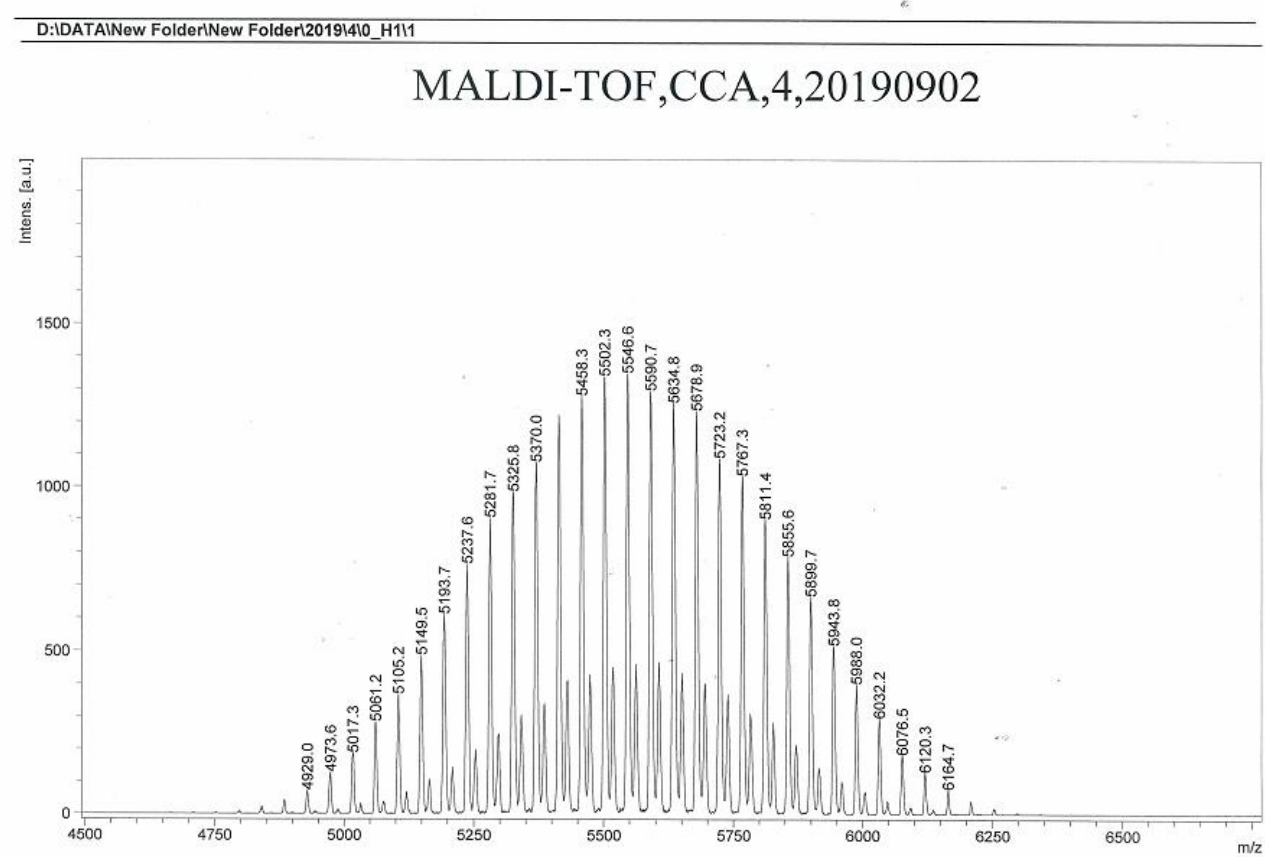

Peptide 10. ${ }^{1} \mathrm{H}$ NMR $\left(400 \mathrm{MHz}, \mathrm{CD}_{3} \mathrm{OH}\right)$

20190726-jiang $2 x-3$

10

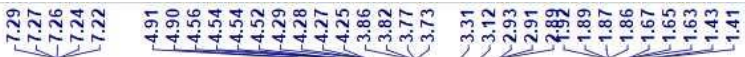

${ }^{1} \mathrm{HNMR}\left(\mathrm{CD}_{3} \mathrm{OH}, 400 \mathrm{MHZ}\right)$

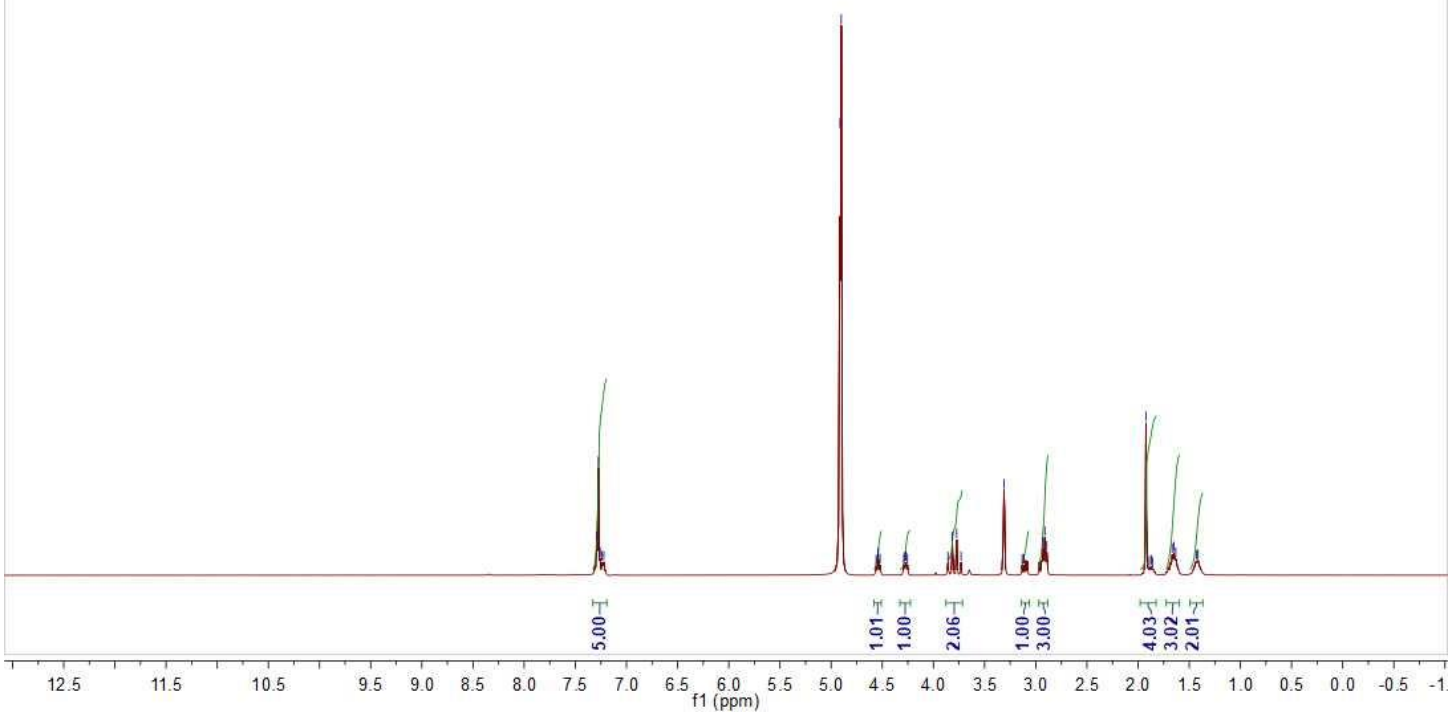


Peptide 10. ${ }^{13} \mathrm{C}$ NMR (100 MHz, $\left.\mathrm{D}_{2} \mathrm{O}\right)$

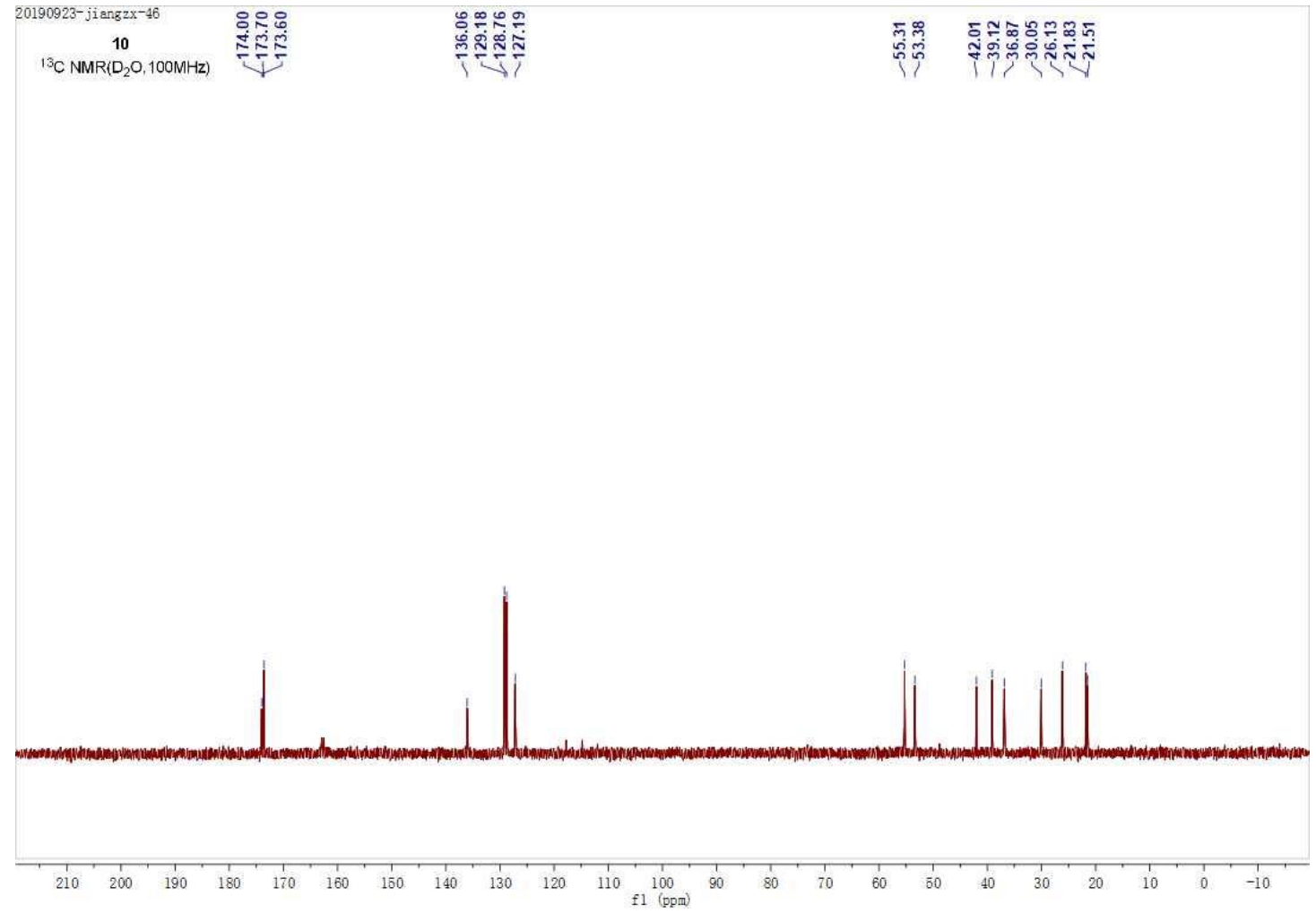

\section{Peptide 10. HRMS (ESI)}

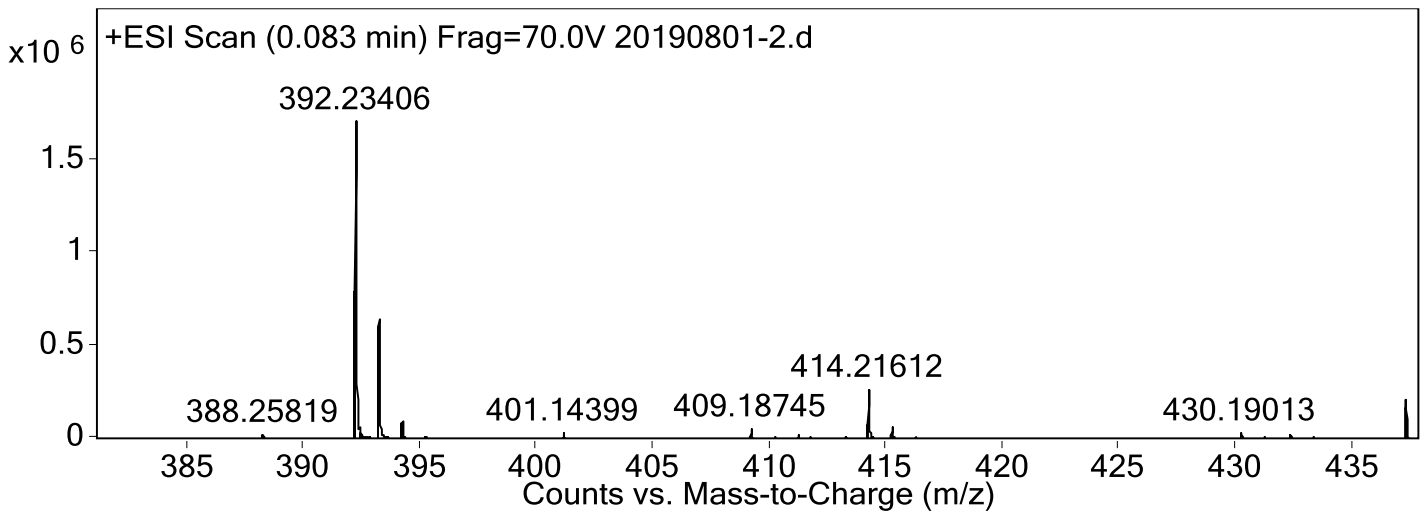


11 Maldi-Tof mass spectrum

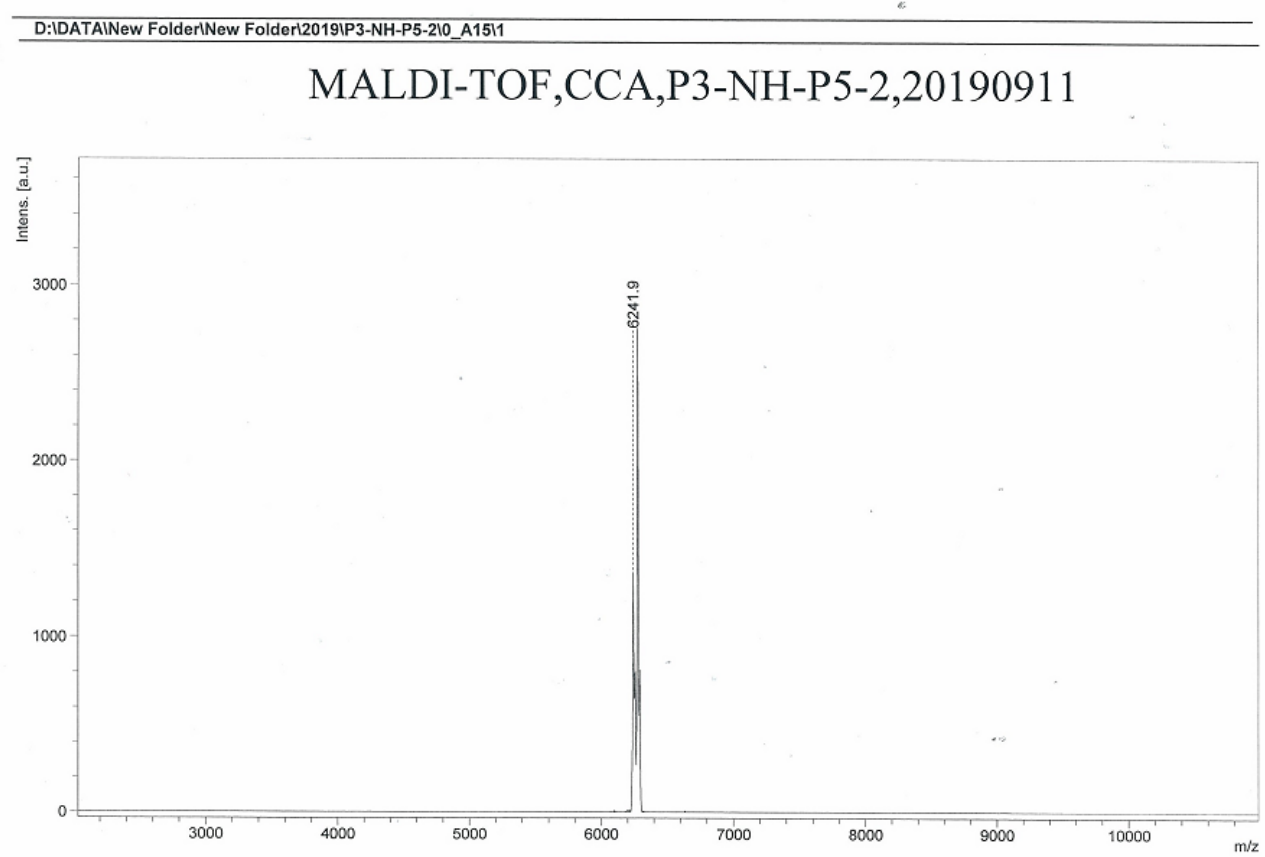

12 Maldi-Tof mass spectrum

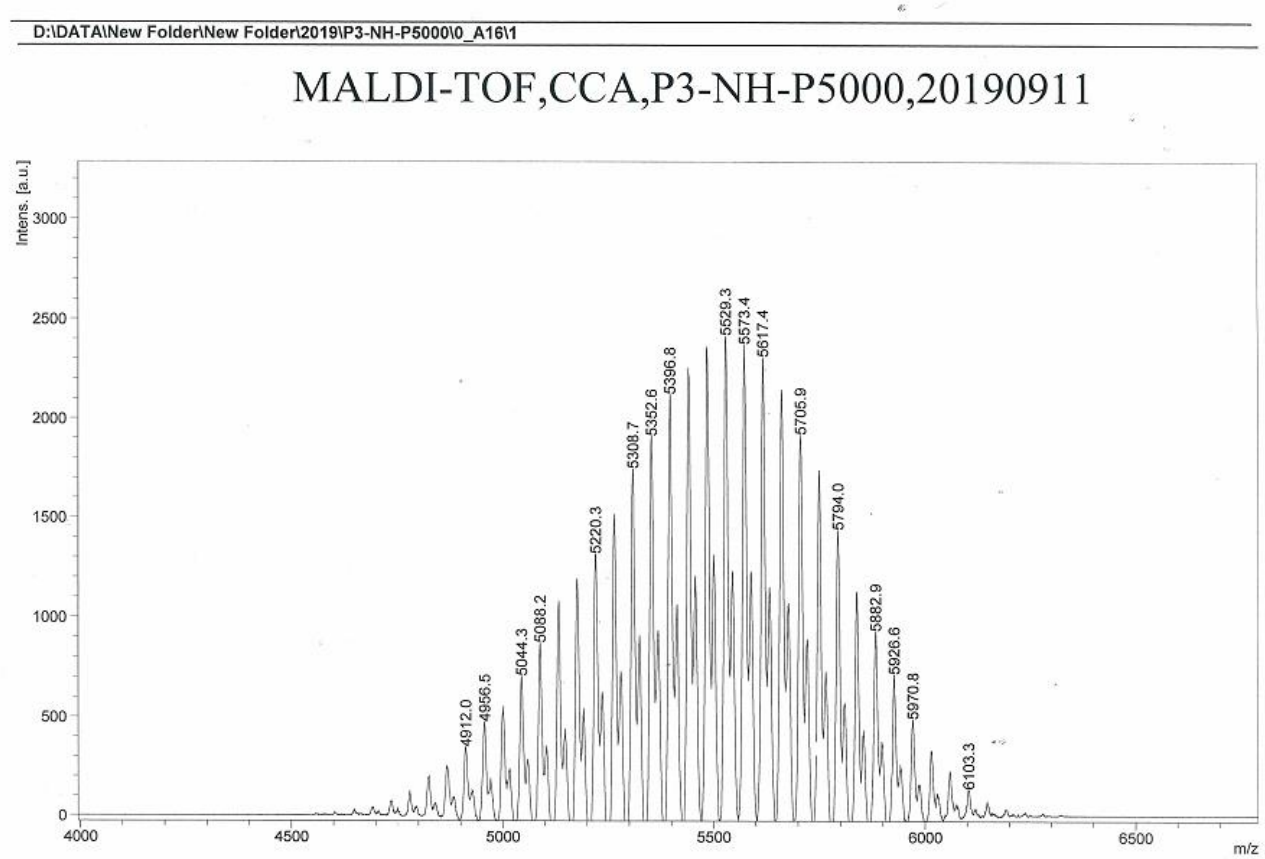


15 Maldi-Tof mass spectrum

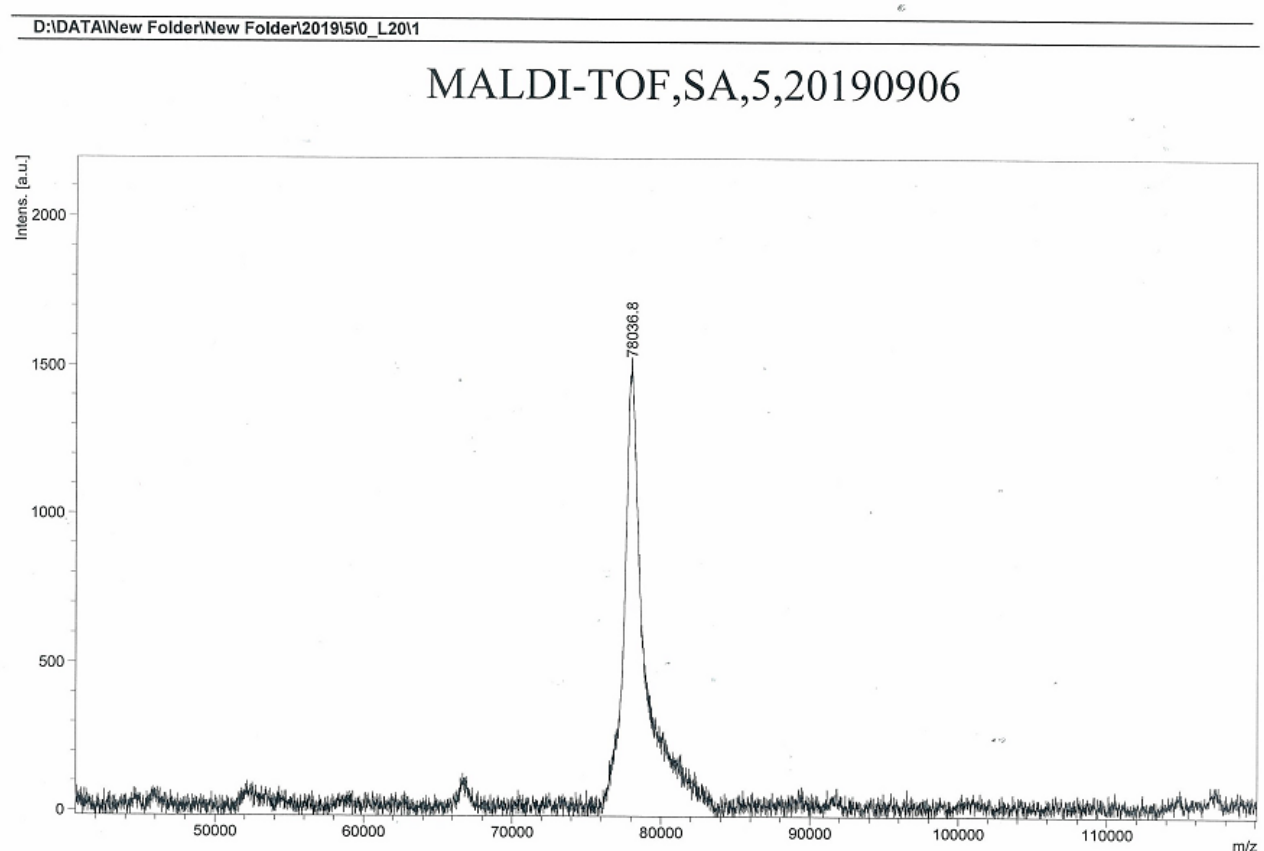

16 Maldi-Tof mass spectrum

MALDI-TOF,SA,3,20190906

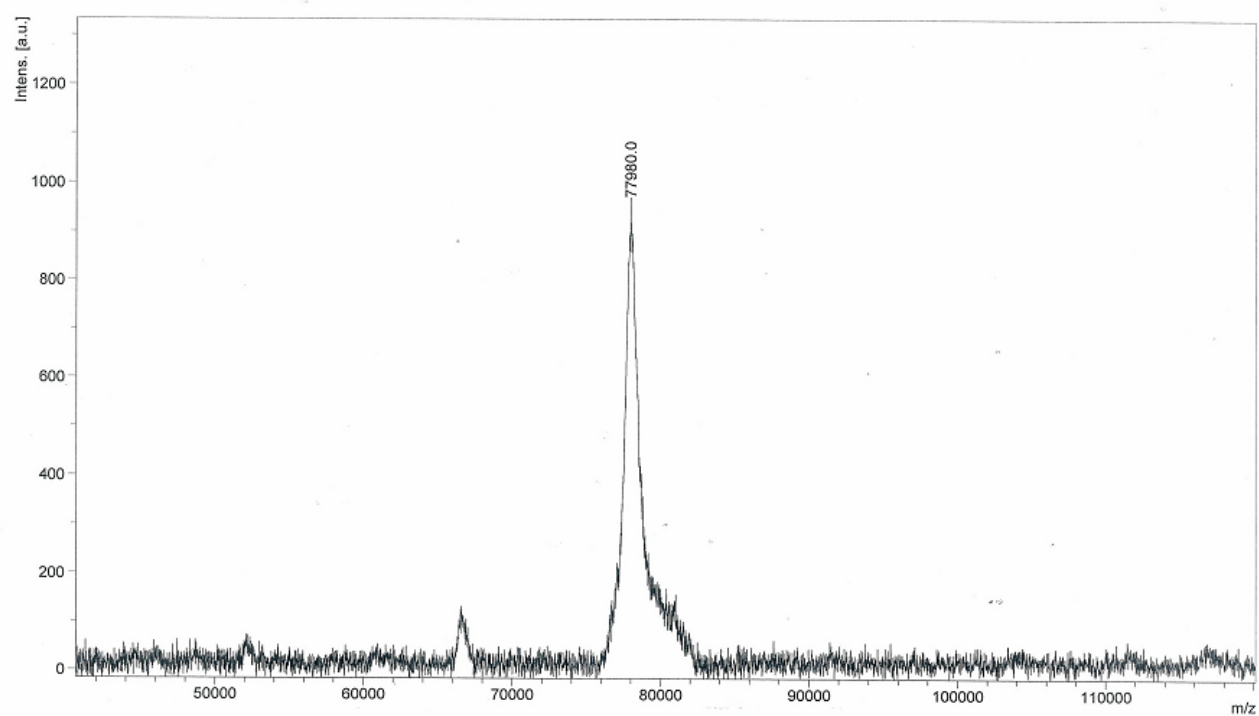


17 Maldi-Tof mass spectrum

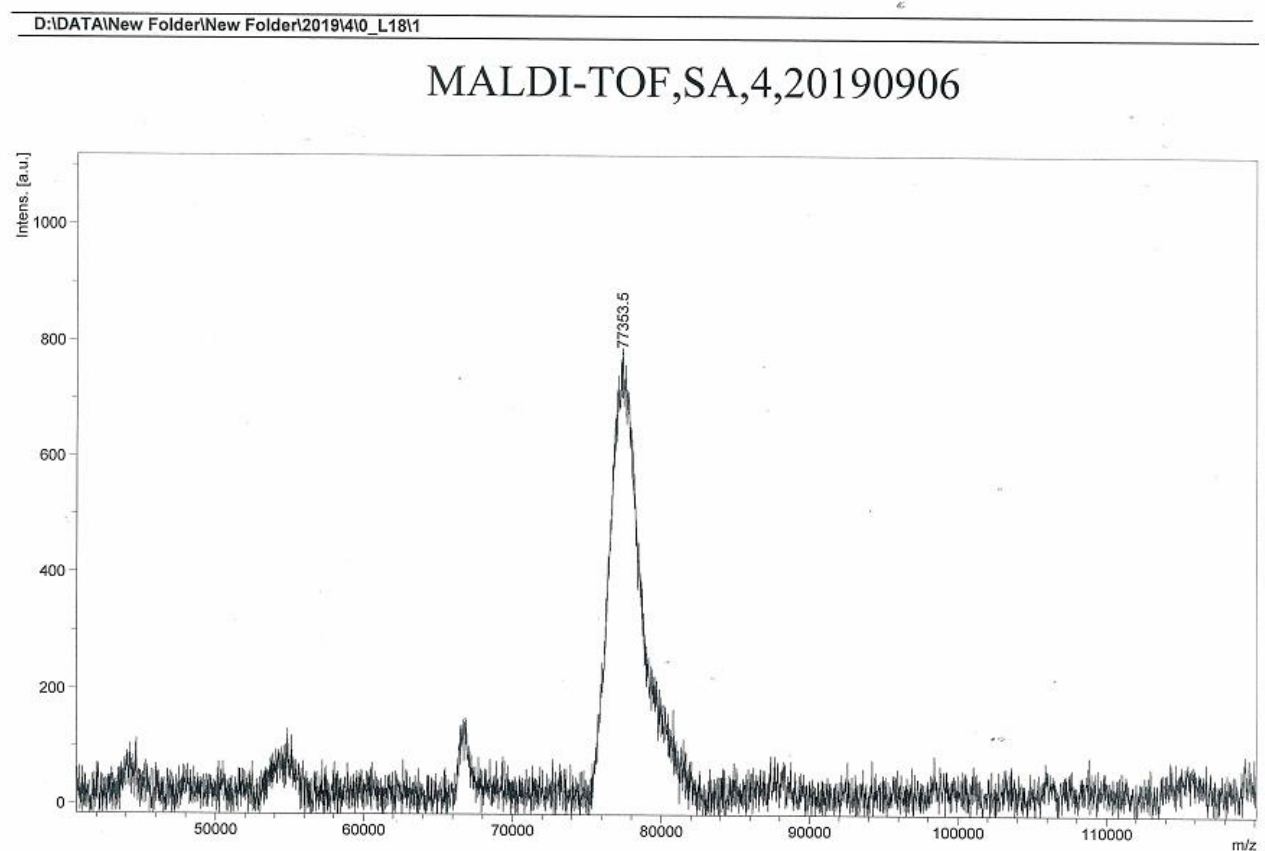

18 Maldi-Tof mass spectrum

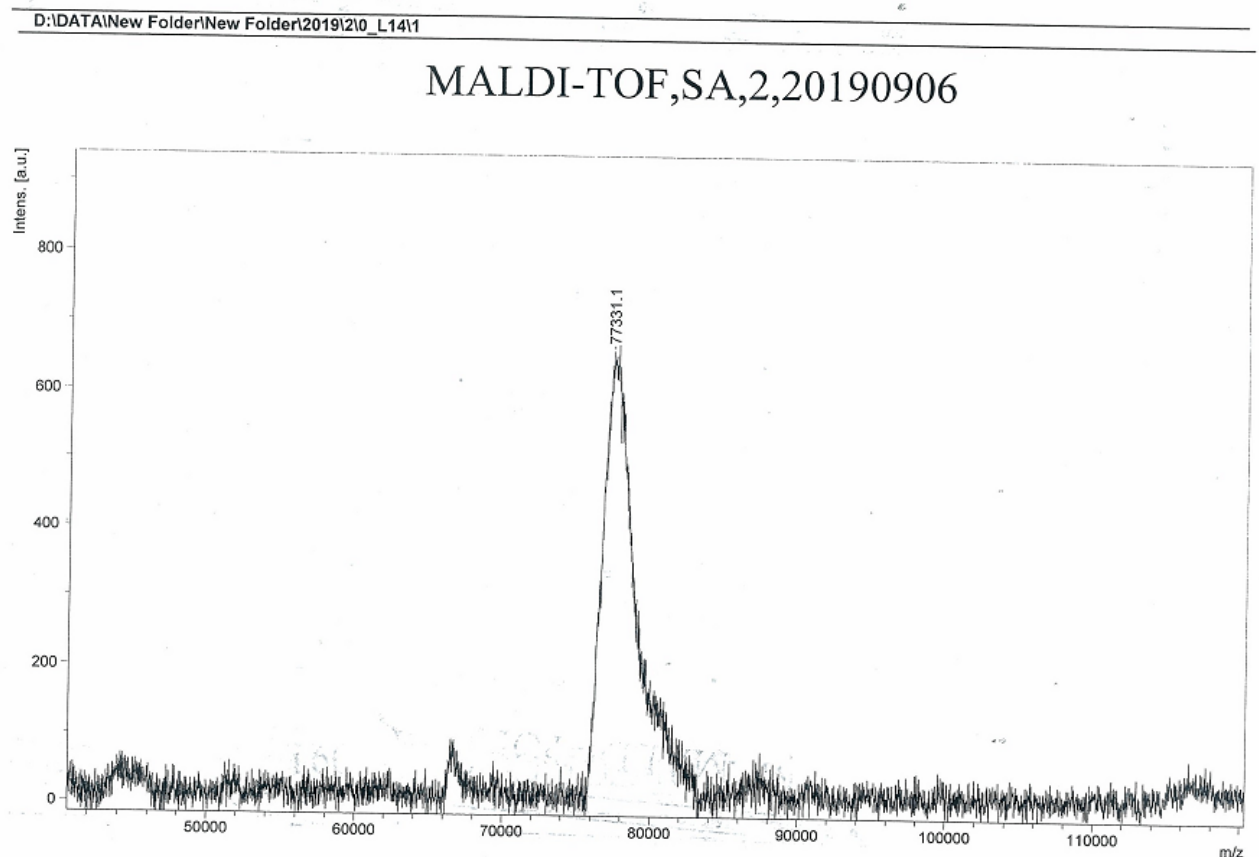

